\title{
Numerical study of combined wave overtopping and storm surge overflow of HPTRM strengthened levee
}

\author{
Lin $\mathrm{Li}^{1}$, Saiyu Yuan ${ }^{2}$, Farshad Amini ${ }^{1, *}$, and Hongwu Tang ${ }^{2}$ \\ ${ }^{I}$ Department of Civil and Environmental Engineering, Jackson State University, Jackson, \\ Mississippi, 39217, USA \\ ${ }^{2}$ State Key Laboratory of Hydrology-Water Resources and Hydraulic Engineering, Hohai \\ University, Nanjing, China, 210098. \\ *Corresponding author. Tel.: +1 601 9793913; fax: +1 601 9793238. Email address: \\ famini@jsums.edu (F.Amini)
}

\begin{abstract}
Overtopping of earthen levees produces fast-flowing, turbulent water velocities on the land-side slope that can damage the protective grass covering and expose the underlying soil to erosion. High performance turf reinforcement mat (HPTRM) is one of the most advanced flexible armoring technologies for severe erosion challenges. In this study, combined wave overtopping and storm surge turbulent overflow of a HPTRM strengthened levee was studied in a three-dimension numerical modeling. The primary objective was to investigate the hydrodynamics of the combined overtopping turbulent flow on the land-side levee slope. Thirty combined overtopping cases with different freeboards and significant wave heights were simulated. After verifying the numerical model with full-scale overtopping experimental data and previous equations, new equations were developed to estimate average overtopping discharge, mean flow
\end{abstract}


thickness, characteristic parameters of wave height and flow thickness, and wave front velocity at the toe of the land-side levee slope for the HPTRM strengthened levee. The range of the application of these equations is discussed.

Keywords:

Combined wave overtopping and storm surge overflow, high performance turf reinforcement mat, numerical modeling, levee

\section{Introduction}

Overtopping of earthen levees produces fast-flowing, turbulent water velocities on the landside slope that can damage the protective grass covering and expose the underlying soil to erosion (Sills et al., 2008). The rapid loss of unprotected soil during long overtopping event may eventually result in loss of levee crest elevation, and possibly breaching of the protective structure (Hughes and Nadal, 2009). Post-Katrina investigations revealed that most earthen levee damage occurred on the levee crest and landward-side slope as a result of either wave overtopping, storm surge overflow, or a combination of both (e.g., ASCE Hurricane Katrina External Review Panel, 2007). Thus, the crest and land-side slopes of those levees that are at risk of overtopping must be protected with some type of strengthening method such as turf reinforcement, soil 
strengthening, or hard armoring (Pullen et al., 2007; van der Meer et al., 2009).

High Performance Turf Reinforcement Mat (HPTRM), as one of the levee strengthening systems, has been proposed to protect the crest and land-side slope of levees. HPTRM is a combination of nylon filaments matrix and polyester geogrid reinforcement at low strains to lock soil in place, and provides permanent reinforcement to prevent soil loss during storm events. It is a lightweight material (in the range of 666

$\mathrm{g} / \mathrm{m}^{2}$ ), that places the minimum load on levee as strengthening materials (Goodrum, 2011). The effect of HPTRM as levee strengthened materials has been studied in full-scale overtopping tests (Pan et al., 2013; Yuan et al., 2014a). There is little information about the hydrodynamics at the toe of the land-side levee slope in the HPTRM strengthened levee under combined wave overtopping and storm surge overflow.

\section{Literature Review}

Most levee overtopping work has been conducted with physical models (e.g. Hanson et al., 2005; van der Meer et al., 2009; Hughes and Nadal, 2009; Pan et al., 2013; Yuan et al., 2014a). The combined wave overtopping and storm surge overflow can cause much more severe impact than the surge-only overflow (Hughes and Nadal, 2009). During this combined condition, the average overtopping discharge and the peak instantaneous discharge can be several times the value of the surge-only overflow discharge.

In Eurotop Manual (Pullen et al., 2007), the total overtopping discharge $q_{w s}$ of 
combined wave overtopping and storm surge overflow was attributed to surge overflow and to wave-only overtopping:

$$
\begin{aligned}
& q_{w s}=0.5443 \sqrt{g}\left(-R_{c}\right)^{3 / 2}+\sqrt{g H_{m 0}^{3}}\left(0.136-\frac{0.226}{\xi_{m-1,0}^{3}}\right) \quad \text { for } \quad \xi_{m-1,0}>2.0 \\
& q_{w s}=0.5443 \sqrt{g}\left(-R_{c}\right)^{3 / 2}+\sqrt{g H_{m 0}^{3}}\left(0.0537 \cdot \xi_{m-1,0}\right) \quad \text { for } \quad \xi_{m-1,0}<2.0
\end{aligned}
$$

where $g$ is the gravitational acceleration; $R_{c}$ is the free board which is the difference between levee crest levee and still sea level, and should be negative for surge overflow; $H_{m 0}$ is the energy-based significant wave height, and $\xi_{m-1,0}$ is Iribarren number based on deepwater wave length and mean energy period.

Reeve et al. (2008) conducted a numerical simulation based on the Reynolds-averaged Navier-Stokes equations to investigate the discharge characteristics of combined wave overtopping and storm surge overflow of impermeable seawalls. Formulae for average discharge corresponding to combined wave overtopping and storm surge overflow were given for small negative freeboard $\left(0<-R_{c} \leq 0.8 \mathrm{~m}\right)$ :

$q_{w s}=\sqrt{g H_{s}^{3}}\left(0.233 \exp \left(1.29\left(-R_{c} / H_{s}\right)\right)\right) \quad$ for non-breaking waves 
$q_{w s}=\sqrt{g H_{s}^{3}} \frac{\xi_{p}}{\sqrt{\tan \alpha}}\left(0.051 \exp \left(\left(1.98 / \xi_{p}\right)\left(-R_{c} / H_{s}\right)\right)\right) \quad$ for breaking waves

where $\alpha$ is the sea-side slope angle, $H_{s}$ is significant wave height, $\xi_{p}$ is surf-similarity parameter defined as $\xi_{p}=\tan \alpha / \sqrt{S_{p 0}}$, and $S_{p 0}$ is the deep water wave steepness.

Hughes and Nadal (2009) conducted a two-dimensional laboratory study on combined wave overtopping and storm surge overflow of a levee with a trapezoidal cross section in nominal prototype-to-model length scale of 25-to-1. A total of 27 wave conditions for combined wave overtopping and storm surge overflow were tested. Overtopping discharge was given as a function of relative freeboard as:

$q_{w s}=\sqrt{g H_{m 0}^{3}}\left(0.034+0.53\left(-R_{c} / H_{m 0}\right)^{1.58}\right)$

where $R_{c} / H_{m 0}$ is relative freeboard, defined as the ratio of freeboard $\left(R_{c}\right)$ to the significant wave height $\left(H_{m 0}\right)$. The relative freeboard reflects the proportional relationship between surge overflow and wave overtopping in the combination of surge and wave overtopping. Hughes and Nadal (2009) compared their equation with Reeve et al. (2008) and concluded that Eqs. (3)-(4) gave lower estimates.

The average flow thickness $\left(d_{m}\right)$, root-mean-square slope-perpendicular wave height $\left(H_{r m s}\right)$, time-domain significant slope-perpendicular wave height parameter $\left(H_{1 / 3}\right)$, corresponding peak wave flow thickness $\left(h_{r m s}\right.$ and $\left.h_{1 / 3}\right)$, and wave front velocity $\left(v_{w}\right)$ on 
the land-side slope can be estimated as (Hughes and Nadal 2009):

$d_{m}=0.4\left(\frac{q_{w s}^{2}}{g \cdot \sin \theta}\right)^{1 / 3}$

$$
\frac{H_{r m s}}{d_{m}}=3.43 \cdot \exp \left(\frac{R_{c}}{H_{m 0}}\right), \text { for } R_{c}<0
$$

$$
H_{1 / 3}=1.416 H_{r m s}
$$

$$
h_{r m s}=H_{r m s} \exp \left[0.32\left(-\frac{R_{c}}{H_{m 0}}\right)^{1.46}\right]
$$

$$
h_{1 / 3}=1.416 H_{r m s} \exp \left[0.18\left(-\frac{R_{c}}{H_{m 0}}\right)^{1.81}\right]
$$

$$
v_{w}=3.85 \sqrt{g H_{r m s}}
$$

where $\theta$ is land-side levee slope angle.

Full-scale laboratory studies on the performances of HPTRM levee strengthening systems under combined wave overtopping and storm surge overflow were conducted in the large wave flume at Oregon State University (Pan et al., 2013; Yuan et al., 2014a). 
The large wave flume is a $104 \mathrm{~m}$ long by $3.66 \mathrm{~m}$ wide by $4.57 \mathrm{~m}$ deep flume equipped with a unidirectional piston wave maker. The physical model was set up at full scale with 1:1 ratio, as shown in Fig. 1a. The tested levee cross section was built $39.8 \mathrm{~m}$ from the wave maker with the crest elevation $3.25 \mathrm{~m}$ above the wave flume bottom. Sea-side of the levee model section had a $1 \mathrm{~V}: 4.25 \mathrm{H}$ slope and the land-side slope was $1 \mathrm{~V}: 3 \mathrm{H}$. The levee model was designed according to the typical cross section of the levees along the Mississippi River Gulf Outlet. The slope protection model installed on the crest and land-side slope of the levee was a vegetated HPTRM system. The vegetated HPTRM system included grass, HPTRM, and soil. The height of grass was over $0.15 \mathrm{~m}$ before the full-scale overtopping tests.

As shown in Fig.1b, nearly $95 \%$ of the space is open in the turf reinforced mat. As the grass roots grow through the open space of HPTRM, roots become entwined within the turf reinforced mat. The interlocking between roots and turf reinforced mat can enhance the roots resistance against hydraulic lift and shear forces created by high water flow hydraulic erosion. Multiple acoustic Doppler velocimeters were used to measure the flow velocity in the levee crest and land-side slope in the full-scale overtopping tests. Acoustic range finders were employed to measure the flow thickness on the levee section (Pan et al., 2013; Yuan et al., 2014a).

Based on full-scale combined surge and wave overtopping tests on the HPTRM strengthened levee with nine wave conditions, Pan et al. (2013) developed formulae for 
the average overtopping discharge during the combined surge and wave overtopping as:

$$
q_{w s}=0.0053 \sqrt{g H_{m 0}^{3}}+0.378 \sqrt{g}\left(-R_{c}\right)^{3 / 2}\left(-R_{c} / H_{m 0}\right)^{0.08} \quad \text { for } R_{c} / H_{m 0}<-0.3
$$

$$
q_{w s}=2 \sqrt{g}\left(-R_{c}\right)^{3 / 2}+5.59 \sqrt{g}\left(-R_{c}\right)^{3 / 2}\left(R_{c} / H_{m 0}\right) \quad \text { for } R_{c} / H_{m 0}>-0.3
$$

Empirical formula was developed to estimate the average overtopping discharge for the combined wave and surge overtopping of a levee strengthened with HPTRM (Yuan et al., 2014a) as:

$$
q_{w s}=\sqrt{g H_{m 0}^{3}}\left(0.055+0.48\left(-R_{c} / H_{m 0}\right)^{1.58}\right)
$$

Hydrodynamics at the toe of land-side levee slope is the concern of many studies where the flow has high speed, high turbulence and small flow thickness, and is also the location of the largest erosion. However, limitations of physical scale or experimental equipment make it difficult to observe the supercritical overtopping flow at the toe of land-side slope. Numerical models are often employed to fill the gaps that physical models have due to limitations of instruments in the wave overtopping studies (Hu et al., 2000; Hubbard and Dodd, 2002; Shiach et al., 2004; Reeve et al., 2008). Reeve et al. (2008) studied the effects of combined wave overtopping and storm surge overflow discharge on earthen levee in a numerical flume. However, there is very limited 
information about the effect of combined wave overtopping and storm surge overflow on the HPTRM strengthened levee, especially at the toe of land-side slope. The goal of this study is to use a numerical flume to study the overtopping hydraulics at the toe of the land-side slope of HPTRM strengthened levee under combined wave overtopping and storm surge overflow.

Princeton Ocean Model (POM) is a widely used ocean model, which can be used to simulate circulation and mixing processes in rivers, estuaries, shelf and slope, lakes, semi-enclosed seas and open and global ocean (Blumberg and Mellor, 1987; Ezer et al., 2003; Oey et al., 2003; Ezer et al., 2008). POM is a sigma coordinate, free surface ocean model with embedded turbulence and wave sub-models. A wetting and drying (WAD) scheme has been implemented into the POM (named POM-WAD) to simulate flow in near-coast regions where WAD processes prevail (Oey, 2005).

In this study, the POM-WAD model was used to simulate the incidence of random waves on a HPTRM strengthened levee during the combined wave overtopping and storm surge turbulent overflow. The model was verified with empirical equations, experimental results for storm surge overflow and full-scale combined wave overtopping and storm surge overflow, experimental results. After the calibration, the model was used to investigate the hydraulic phenomena of combined wave overtopping and storm surge overflow in the HPTRM strengthened levee, especially at the toe of land-side slope. The erosion on the HPTRM strengthened levee was not within the scope of this study. 


\section{Numerical methodology}

\subsection{Governing equations}

The Navier-Stokes equations under the assumption of hydrostatic pressure and Boussinesq approximation are used in POM-WAD for continuity equation and momentum equations:

$$
\frac{\partial u}{\partial x}+\frac{\partial v}{\partial y}+\frac{\partial w}{\partial z}=0
$$

$$
\frac{\partial u}{\partial t}+u \frac{\partial u}{\partial x}+v \frac{\partial u}{\partial y}+w \frac{\partial u}{\partial z}=-g \frac{\partial \zeta}{\partial x}+\frac{\partial}{\partial x}\left(\varepsilon_{h} \frac{\partial u}{\partial x}\right)+\frac{\partial}{\partial y}\left(\varepsilon_{h} \frac{\partial u}{\partial y}\right)+\frac{\partial}{\partial z}\left(\varepsilon_{z} \frac{\partial u}{\partial z}\right)
$$

$$
\frac{\partial v}{\partial t}+u \frac{\partial v}{\partial x}+v \frac{\partial v}{\partial y}+w \frac{\partial v}{\partial z}=-g \frac{\partial \zeta}{\partial y}+\frac{\partial}{\partial x}\left(\varepsilon_{h} \frac{\partial v}{\partial x}\right)+\frac{\partial}{\partial y}\left(\varepsilon_{h} \frac{\partial v}{\partial y}\right)+\frac{\partial}{\partial z}\left(\varepsilon_{z} \frac{\partial v}{\partial z}\right)
$$

$$
\frac{\partial P}{\partial z}=-\rho g
$$

where $t$ is time; $u, v$, and $w$ are the flow velocity components in the $x, y$, and $z$ directions, respectively; $\zeta$ is the sea level; $z$ is the vertical coordinate increasing upward with $z=0$ located at the undisturbed water surface, and positive upward; $P$ is the water pressure; $\rho$ 
is the water density; $g$ is the gravitational acceleration; $\varepsilon_{h}$ and $\mathcal{E}_{₹}$ are the eddy viscosity of turbulent flow in the horizontal and vertical directions, respectively.

The Mellor-Yamada Level 2.5 turbulence closure model (Mellor and Yamada, 1982) and a prognostic equation (Mellor et al., 1998) for the turbulence macroscale are used to calculate the vertical eddy viscosity and diffusivity. The Mellor-Yamada Level 2.5 turbulence closure includes two partial differential equations to compute the turbulent kinetic energy $\left(q^{2}\right)$ and a turbulent macroscale $(l)$. The equation for the turbulent kinetic energy (without considering the variation of flow density) is:

$\frac{\partial q^{2}}{\partial t}+u \frac{\partial q^{2}}{\partial x}+v \frac{\partial q^{2}}{\partial y}+w \frac{\partial q^{2}}{\partial z}=\frac{\partial}{\partial x}\left(\varepsilon_{q} \frac{\partial q^{2}}{\partial x}\right)+\frac{\partial}{\partial y}\left(\varepsilon_{q} \frac{\partial q^{2}}{\partial y}\right)+\frac{\partial}{\partial z}\left(\varepsilon_{q} \frac{\partial q^{2}}{\partial z}\right)+2\left(P_{s}-\frac{q^{3}}{B_{1} l}\right)$

and the equation for the turbulent macroscale is:

$$
\begin{aligned}
\frac{\partial q^{2} l}{\partial t}+u \frac{\partial q^{2} l}{\partial x}+v \frac{\partial q^{2} l}{\partial y}+ & w \frac{\partial q^{2} l}{\partial z}=\frac{\partial}{\partial x}\left(\varepsilon_{q} \frac{\partial q^{2} l}{\partial x}\right)+\frac{\partial}{\partial y}\left(\varepsilon_{q} \frac{\partial q^{2} l}{\partial y}\right)+\frac{\partial}{\partial z}\left(\varepsilon_{q} \frac{\partial q^{2} l}{\partial z}\right) \\
+l E_{1} P_{s} & -\frac{q^{3}}{B_{1}}\left[1+E_{2}\left(\frac{l}{\kappa L}\right)^{2}\right]
\end{aligned}
$$

where $P_{s}$ is the shear production, defined as $P_{s}=\varepsilon_{z}\left(\frac{\partial u}{\partial z}\right)^{2}+\varepsilon_{z}\left(\frac{\partial v}{\partial z}\right)^{2}, q^{3} / B_{1} l$ is the turbulent dissipation; $L$ is defined as $(\zeta-z)^{-1}+\left(H^{\prime}+z\right)^{-1} ; H^{\prime}$ is the average water depth at mean water level; $\varepsilon_{q}\left(=q / \chi_{q}\right)$ is the eddy diffusion coefficient for turbulence energy; $\mathcal{E}_{z}$ is 
the vertical eddy viscosity, constant $E_{1}$ is 1.8 , constant $E_{2}$ is 1.33 , constant $\chi_{\mathrm{q}}$ is 0.2 and $\kappa$ is the von Karman constant. The last term in Eq. (20) accounts for the effects of solid walls and the free surfaces on the length scale (Mellor and Yamada, 1982). The vertical eddy viscosity $\varepsilon_{z}$ is defined as $\varepsilon_{z}=q l \chi_{z}$. The coefficients $\chi_{z}$ is stability function related to Richardson number, and given by:

$$
\chi_{z}=\frac{A_{2}\left(1-6 A_{1} / B_{1}\right)}{1-3 A_{2} G_{H}\left(6 A_{1}+B_{2}\right)}
$$

where $G_{H}=0$ without considering the variation of flow density, and the constants used in Eq. (21) are $A_{1}=0.92, A_{2}=0.74, B_{1}=16.6$, and $B_{2}=10.1$ (Mellor and Yamada, 1982).

\subsection{Conceptual model}

The conceptual model of a levee embankment strengthened by HPTRM on the crest and along the land-side slope has the same geometry as the levee embankment built during the full-scale overtopping tests of Pan et al. (2013). The dimension of the levee embankment in the conceptual model is $26.12 \mathrm{~m}$ long x $3.25 \mathrm{~m}$ high x $3.66 \mathrm{~m}$ wide (Fig. 1a). The distance between the toe of sea-side slope and the upstream boundary is $39.8 \mathrm{~m}$. The width of the levee crest along the flow direction is $2.57 \mathrm{~m}$. The sea-side has a slope of $1 \mathrm{~V}: 4.25 \mathrm{H}$, and the land-side slope is $1 \mathrm{~V}: 3 \mathrm{H}$. To reduce the impact of the reflection of 
wave at the downstream boundary, a sufficiently large reservoir was used at the downstream boundary.

\subsection{Boundary conditions}

Stresses and vertical velocity are assigned for the boundary conditions at the free water surface and solid boundary on the levee embankment, which can be expressed by:

$\rho \varepsilon_{z}\left(\frac{\partial u}{\partial x}, \frac{\partial v}{\partial x}\right)=\left\{\begin{array}{cl}(0,0) & \text { at water surface } \\ \left(\tau_{b x}, \tau_{b y}\right) & \text { on the levee }\end{array}\right.$

$w= \begin{cases}\frac{\partial \zeta}{\partial t}+u \frac{\partial \zeta}{\partial x}+v \frac{\partial \zeta}{\partial y} & \text { at water surface } \\ -u \frac{\partial H^{\prime}}{\partial x}-v \frac{\partial H^{\prime}}{\partial y} & \text { on the levee }\end{cases}$

The boundary conditions of turbulence energy and turbulence macroscale applied at the water surface and solid boundaries, respectively, are

$q^{2}=B_{1}^{2 / 3} u_{*}^{2}$

$q^{2} l=0$ 
where $u_{*}$ is friction velocity associated with the bottom frictional stress $\left(\tau_{b x}, \tau_{b y}\right)$. The bottom frictional stresses can be determined by:

$$
\tau_{b}=\rho C_{D}\left|U_{b}\right| U_{b}
$$

where $C_{D}$ is drag coefficient and $U_{b}$ is the velocity in the grid point nearest the solid boundary. Stephan and Gutknecht (2002) defined the drag coefficient as:

$$
C_{D}=\left(\frac{1}{\kappa} \ln \frac{D-y^{\prime \prime}}{y^{\prime \prime}}+8.5\right)^{-2}
$$

where $D$ is the water depth, $\kappa$ is the von Karman constant $(=0.4)$, and $y$ " is the mean deflected plant height. For the flow passing over the grass, there are two flow zones: one within the grass and another above it. The flow zone above the grass is characterized by the logarithmic velocity profile, and its zero is raised by the deflected plant height $y$ ”, as shown in Fig. 2. The deflected plant height $y^{\prime \prime}$ is a critical parameter (length scale) in this model, because it affects the drag coefficient $C_{D}$, and the bottom frictional stresses. The plant covering increases the bed surface roughness and the vertical velocity distribution. 


\subsection{Initial conditions}

The upstream water level was the same as the levee crest height, and there was not any water along the land-side slope and in the downstream reservoir. The wave was generated at $39.8 \mathrm{~m}$ away from the sea-side slope toe. The initial input conditions were eleven surge elevations ( $h_{1}$ from $+0.2 \mathrm{~m}$ to $+1.2 \mathrm{~m}$ above the levee crest, $h_{l}=-R_{c}$ ) in the storm surge overflow. For the combined wave overtopping and storm surge overflow, the initial input conditions were three surge elevations $\left(h_{1}=+0.3,+0.6\right.$, and $+0.9 \mathrm{~m}$ above the levee crest), fifteen significant wave heights ( $H_{m 0}$ from $0.15 \mathrm{~m}$ to $1.8 \mathrm{~m}$ ), and two peak wave periods ( $T_{p}=7$ and $10 \mathrm{~s}$ ). This yielded a total of 30 unique conditions for combined wave overtopping and storm surge overflow.

\subsection{Random wave generation}

Random waves were applied as the upstream (sea-side) boundary condition for water level. The random waves were generated using the parameterized Joint North Sea Wave Project (JONSWAP)-spectrum (Goda, 1999) as: 
$S(f)=\frac{0.06238\left(1.094-0.01915 \ln \gamma^{\prime}\right)}{0.230+0.0336 \gamma^{\prime}-0.185\left(1.9+\gamma^{\prime}\right)^{-1}} H_{s}^{2} T_{p}^{-4} f^{-5} \exp \left(-1.25 T_{p}^{-4} f^{-4}\right) \gamma^{\exp \left(-\left(T_{p} f-1\right)^{2} / 2 \sigma^{2}\right)}$

where $S(f)$ is the spectral density function, $H_{s}$ is the significant wave height $\left(=H_{1 / 3}\right.$; defined as average of highest $1 / 3$ waves); $T_{p}$ is the peak wave period, $f$ is the wave frequency and $\gamma$ is the spectral enhancement factor, and $\sigma$ is 0.07 for $T_{p} f \leq 1$ or 0.09 for $T_{p} f>1$. The spectral enhancement parameter $\gamma$ is in the range of 1 to 6 and has a normal distribution with a mean of 3.3 and a standard deviation of 0.79 (Hasselmann, 1973).

In wave overtopping studies, $H_{s}$ is usually replaced with energy-based significant wave height, $H_{m 0}$ (Schüttrumpf et al., 2001; Hughes and Nadal, 2009; Rao et al., 2012; Pan et al., 2013). In this paper, $H_{m 0}$ is also employed as the representative wave parameter and calculated by analyzing the generated random wave from Eq. (28). The $H_{m 0}$ is defined as:

$H_{m 0}=4.004 \sqrt{m_{0}}$

where $m_{0}$ is the 0 -th spectral moment. The $m_{0}$ can be solved by:

$m_{0}=\int_{0}^{\infty} E(f) d f$ 
where $E(f)$ is the spectral energy density and $f$ is the frequency. One example of the generated random wave with energy-based significant wave height $\left(H_{m 0}\right)$ of $0.778 \mathrm{~m}$ and peak wave period $\left(T_{p}\right)$ of $7.0 \mathrm{~s}$ is shown in Fig. 3.

\subsection{Numerical scheme}

The $\sigma$-coordinate transformation, which was developed by Lu and Wai (1998), is used to solve the hydrodynamic equations and mass conservation and transport equations in three sub-steps: (a) the advection term in momentum equations (Eq. (16) and Eq. (17)) and kinetic energy of turbulence and macroscale of turbulent eddy are solved by the Eulerian-Lagrangian method (Eq. (19) and Eq. (20)); (b) the horizontal diffusion terms in the momentum equations are approximated by the implicit finite element method; and (c) the vertical diffusion terms in the momentum equations, the vertical dispersion terms and source-sink terms in the scalar transport equations are solved by the implicit finite difference method.

\subsection{Sensitivity analysis}

The size of the domain and the level of discretization were determined based on a sensitivity analysis. This analysis identified the domain size needed so that overtopping 
hydraulics was not affected by the boundaries and the grid spacing. The grid spacing for lateral flow $(y)$ direction was $0.25 \mathrm{~m}$ with a total of 16 cells. Because the water thickness changes along the flow direction on the crest and landside slope, the grid spacing for vertical flow $(\mathrm{z})$ direction varied from 0.008 (crest) to $0.025 \mathrm{~m}$ (landslide slope) with a total of 10 cells, respectively. In the longitudinal (flow) direction, the cell size varied from $0.05 \mathrm{~m}$ to $0.25 \mathrm{~m}$. As shown in Fig. 4 , the three grid setups are almost the same in the flow $(x)$ direction except for the different grid resolution on the crest and land-side slope. The coarse grid is $0.25 \mathrm{~m}$ long ( $x$ direction) with a total of 10 cells on the crest and 38 cells on the land-side slope. The medium cell is $0.1 \mathrm{~m}$ long with a total of 25 cells on the crest and 96 cells on the land-side slope. The fine grid is $0.05 \mathrm{~m}$ long with a total of 50 cells on the crest and 192 cells on the land-side slope. One test was performed using the three-dimensional hydrodynamic model (Eqs. (15) to (20)) to compare the simulation results using the three grid systems for the storm surge overflow with an inflow surge depth of $0.3 \mathrm{~m}$.

Fig. 5 shows the comparison of predicted overtopping discharge and streamwise velocity from the beginning of the crest to the toe of the land-side slope for the three grid systems. The overtopping discharge and the streamwise velocity are sensitive to the grid resolution, specifically near the transition from the crest to the land-side slope $(x=55.9$ m). The coarse grid did not simulate the complex flow structure near the transition very 
well, while the fine and medium grid provided similar results. Hence, the medium grid was considered optimal and was selected for the simulations.

\section{Results and discussion}

The 3D model, POM-WAD, was first calibrated with experimental results for storm surge overflow. The model was then verified with some empirical formulae and published laboratory measurements for combined wave overtopping and storm surge overflow. The model was used to study the overtopping hydraulics of combined wave overtopping and storm surge overflow on the HPTRM strengthened levee, especially at the toe of land-side slope. Due to the length limitation, the related shear stress and erosion are not included in this paper. The shear stress analysis and erosion, can be found in another manuscript (Yuan, et al., 2014b).

\subsection{Model calibration}

In this study, experimental data from full-scale overtopping tests on the HPTRM strengthened levee (Pan et al., 2013) were used to calibrate unknown hydrodynamic parameter, the deflected plant height $y$ ", and to verify the validation of this 3D model.

Grass covering and rough mat increases the levee's bed surface roughness. The bed 
shear stress has a dominant effect on the momentum balances that control the magnitude and vertical structure of wave-driven flow and its distribution. As shown in Fig. 2, the deflected plant height $y$ " is a key parameter to determine the drag coefficient and the bed shear stress and thus the vertical velocity profile.

The model calibration was performed by adjusting deflected plant height to match predicted flow velocity, flow thickness and overflow discharge to the experimental measurements. The surge-only overflow experimental results with a freeboard $\left(-R_{c}\right)$ of $0.3 \mathrm{~m}$ were used in the model calibration (Pan et al, 2013). Based on the experimental observation, the height of deflected grass was almost unchanged during the entire overtopping testing. Because the flow velocity is very fast, it is difficult for deflected grass to recover. The average value of measured deflected plant height $y$ " was $1.25 \mathrm{~cm}$ (Pan et al, 2013). The measured flow velocity, flow thickness, and overflow discharge at the two survey locations on the levee crest and on the land-side slope are included in Table 1. The modeling predictions of flow velocity, flow thickness and overflow discharge for the storm surge overflow with a surge height of $0.3 \mathrm{~m}$ are also shown in Table 1. As seen, simulated flow velocity $V$ and flow thickness $D$ agree well with the experiment observation, which suggests that the deflected plant height of $1.25 \mathrm{~cm}$ is a reasonable value for the mean deflected height of grass in the hydrodynamic simulation of levee overtopping. 


\section{Table 1}

Comparison of model prediction and experimental measurement at the storm surge overflow with a surge height of $0.3 \mathrm{~m}$.

\begin{tabular}{|c|c|c|c|c|c|c|c|c|c|}
\hline \multirow[t]{2}{*}{ Location } & \multicolumn{3}{|c|}{$\begin{array}{l}\text { Experiments of } \\
\text { Pan et al. (2013) }\end{array}$} & \multicolumn{3}{|c|}{$\begin{array}{l}\text { Numerical model } \\
\text { (present study) }\end{array}$} & \multicolumn{3}{|c|}{$\begin{array}{c}\text { Difference } \\
\text { between two } \\
\text { methods }\end{array}$} \\
\hline & $\begin{array}{c}V \\
(\mathrm{~m} / \mathrm{s})\end{array}$ & $\begin{array}{c}D \\
(\mathrm{~m})\end{array}$ & $\begin{array}{c}q_{s} \\
\left(\mathrm{~m}^{3} / \mathrm{s}-\mathrm{m}\right)\end{array}$ & $\begin{array}{c}V \\
(\mathrm{~m} / \mathrm{s})\end{array}$ & $\begin{array}{c}D \\
(\mathrm{~m})\end{array}$ & $\begin{array}{c}q_{s} \\
\left(\mathrm{~m}^{3} / \mathrm{s}-\mathrm{m}\right)\end{array}$ & $\begin{array}{c}V \\
(\%)\end{array}$ & $\begin{array}{c}D \\
(\%)\end{array}$ & $\begin{array}{c}q_{s} \\
(\%)\end{array}$ \\
\hline $\begin{array}{l}\text { Middle of } \\
\text { crest }\end{array}$ & 1.320 & 0.167 & 0.220 & 1.320 & 0.169 & 0.223 & 0 & 1.2 & 1.4 \\
\hline $\begin{array}{l}\text { Land-side } \\
\text { slope }\end{array}$ & 2.720 & 0.081 & 0.220 & 2.850 & 0.079 & 0.225 & 4.8 & -2.5 & 2.3 \\
\hline
\end{tabular}

Note: $V$ is the mean flow velocity; $D$ is the mean water thickness; $q_{s}$ is the storm surge overflow discharge per levee width. The "middle of crest" is located at $0.91 \mathrm{~m}$ upstream of the interface between crest and land-side slope. The "land-side slope" is located at 1.22 $\mathrm{m}$ downstream of the interface between crest and land-side slope.

\subsection{Storm surge overflow discharge}

A total of 11 cases of storm surge overflow were simulated with the surge height of $0.2 \mathrm{~m}$ to $1.2 \mathrm{~m}$. Table 2 lists the input freeboard $\left(-R_{c}\right)$ and the output discharges. The $q_{s}$ is steady overflow discharge per unit length.

A comparison of modeling predictions, published laboratory data of storm surge overflow, and empirical solution (Henderson 1966) for the storm surge overflow discharge is shown in Fig. 6. The round points are the laboratory data measured by Pan et al. (2013) and Yuan et al. (2014a) in the full-scale storm surge overflow experiments. The 
modeling predictions are in general agreement with experimental measurements. The numerical modeling results and laboratory data are slightly lower than the broad-weir equation, due to the increased resistance caused by the grass covering and rough mat.

\section{Table 2}

Hydrodynamic parameters and steady overflow discharge for storm surge overflows on the HPTRM strengthened levee.

\begin{tabular}{ccc}
\hline Case number & Freeboard $-R_{c}(\mathrm{~m})$ & $\begin{array}{c}\text { Steady overflow discharge } q_{s} \\
\left(\mathrm{~m}^{3} / \mathrm{s}-\mathrm{m}\right)\end{array}$ \\
\hline S1 & 0.2 & 0.102 \\
S2 & 0.3 & 0.224 \\
S3 & 0.4 & 0.373 \\
S4 & 0.5 & 0.540 \\
S5 & 0.6 & 0.723 \\
S6 & 0.7 & 0.930 \\
S7 & 0.8 & 1.151 \\
S8 & 0.9 & 1.390 \\
S9 & 1.0 & 1.643 \\
S10 & 1.1 & 1.901 \\
S11 & 1.2 & 2.184 \\
\hline
\end{tabular}

\subsection{Combined wave and storm surge overtopping discharge}

The combined wave and storm surge overtopping flow is much more complex than storm surge overflow. Flow down the land-side slope caused by combined waves and surge overtopping is unsteady and more difficult to analyze thoroughly. In this study, a total of 30 tests were run with freeboard $\left(-R_{c}\right)$ ranging from $0.3 \mathrm{~m}$ to $0.9 \mathrm{~m}$, random 
waves with a JONSWAP spectrum, and energy-based significant wave height $\left(H_{m 0}\right)$ ranging from $0.2 \mathrm{~m}$ to $1.8 \mathrm{~m}$. Table 3 lists the input wave parameters for all the 30 cases. Each simulation was performed to generate time sequences with a total duration in excess of $700 \mathrm{~s}$ (corresponding to approximately 100 waves).

Fig. 7 provides an example of for instantaneous free surface output after 20, 22, 24, and $26 \mathrm{~s}$. These free surfaces corresponded to the combined wave overtopping and storm surge overflow with surge height of $0.6 \mathrm{~m}$, energy-based significant wave height of $0.8 \mathrm{~m}$, and peak wave period of $7 \mathrm{~s}$.

Fig. 8 shows the cumulative total and mean overtopping volume calculated by the numerical model at the toe of land-side slope for the combined wave overtopping and storm surge overflow with surge height of $0.3 \mathrm{~m}$, energy-based significant wave height of $0.6 \mathrm{~m}$, and peak wave period of $7 \mathrm{~s}$. The units of overtopping volume are $\mathrm{m}^{3} / \mathrm{s}$ per unit width of meter. The unsteady nature of the overtopping events is clear from Fig. 8. Fig. 8 also shows that the variation in the mean overtopping volume decreases rapidly and becomes very modest after the first $100 \mathrm{~s}$. 
Table 3

Hydrodynamic parameters for combined wave overtopping and storm surge overflow.

\begin{tabular}{|c|c|c|c|c|}
\hline $\begin{array}{c}\text { Case } \\
\text { number }\end{array}$ & $\begin{array}{l}\text { Freeboard } \\
-R_{c}(\mathrm{~m})\end{array}$ & $\begin{array}{c}\text { Energy-based significant } \\
\text { wave height } \\
H_{m 0}(\mathrm{~m})\end{array}$ & $\begin{array}{c}\text { Peak wave } \\
\text { period } \\
T_{p}(\mathrm{~s})\end{array}$ & $\begin{array}{c}\text { Relative } \\
\text { freeboard } \\
-R_{c} / H_{m 0}(-)\end{array}$ \\
\hline SW1 & 0.3 & 0.381 & 7 & 0.787 \\
\hline SW2 & 0.3 & 0.528 & 7 & 0.569 \\
\hline SW3 & 0.3 & 0.566 & 7 & 0.530 \\
\hline SW4 & 0.3 & 0.641 & 7 & 0.468 \\
\hline SW5 & 0.3 & 0.778 & 7 & 0.386 \\
\hline SW6 & 0.3 & 0.897 & 7 & 0.334 \\
\hline SW7 & 0.3 & 1.014 & 7 & 0.296 \\
\hline SW8 & 0.3 & 1.143 & 7 & 0.262 \\
\hline SW9 & 0.3 & 1.277 & 7 & 0.235 \\
\hline SW10 & 0.3 & 1.570 & 7 & 0.191 \\
\hline SW11 & 0.3 & 2.312 & 7 & 0.130 \\
\hline SW12 & 0.3 & 3.132 & 7 & 0.096 \\
\hline SW13 & 0.3 & 3.840 & 7 & 0.078 \\
\hline SW14 & 0.3 & 0.778 & 7 & 0.386 \\
\hline SW15 & 0.3 & 1.570 & 10 & 0.191 \\
\hline SW16 & 0.3 & 0.778 & 10 & 0.771 \\
\hline SW17 & 0.6 & 1.014 & 7 & 0.592 \\
\hline SW18 & 0.6 & 1.570 & 7 & 0.382 \\
\hline SW19 & 0.6 & 2.030 & 7 & 0.296 \\
\hline SW20 & 0.6 & 2.312 & 7 & 0.259 \\
\hline SW21 & 0.6 & 3.132 & 7 & 0.192 \\
\hline SW22 & 0.6 & 3.840 & 7 & 0.156 \\
\hline SW23 & 0.6 & 4.660 & 7 & 0.129 \\
\hline SW24 & 0.6 & 1.143 & 7 & 0.787 \\
\hline SW25 & 0.9 & 1.570 & 7 & 0.573 \\
\hline SW26 & 0.9 & 2.312 & 7 & 0.389 \\
\hline SW27 & 0.9 & 3.132 & 7 & 0.287 \\
\hline SW28 & 0.9 & 3.840 & 7 & 0.234 \\
\hline SW29 & 0.9 & 4.660 & 7 & 0.193 \\
\hline SW30 & 0.9 & 0.381 & 7 & 0.787 \\
\hline
\end{tabular}

Note: freeboard $\left(-R_{c}\right)$ is surge height above crest. 
The wave overtopping discharge rate is a critical parameter in the conceptual and preliminary design of levees. Based on physical experiments and numerical models, several empirical formulas are available to predict overtopping of levees under given wave conditions and storm surge levels (e.g., Schüttrumpf et al., 2001; Reeve et al., 2008; Hughes and Nadal, 2009; Rao et al., 2012; Pan et al., 2013). The overtopping discharge depends on wave parameters and structural parameters, including crest geometry, sea-side slope, land-side slope, significant wave height, peak wave period, and water depth at the toe of land-side slope. A detailed review of the overtopping discharge for surge overflow, wave overtopping, and combined wave and surge overtopping conditions can be found in Hughes and Nadal (2009).

Fig. 9 shows the dimensionless overtopping discharge for combined wave and storm surge overtopping as a function of the relative (negative) freeboard. As shown, the dimensionless overtopping discharge has a nice trend with increasing relative freeboard. A best-fit curve can be described as:

$\frac{q_{w s}}{\sqrt{g H_{m 0}^{3}}}=0.034+0.457\left(\frac{-R_{c}}{H_{m 0}}\right)^{1.4} ; \quad R_{c}<0$

The best-fit equation had a correlation coefficient of 0.996 and a root-mean-square error of 0.008 . Note that $R_{c}$ must be entered as a negative number so the ratio in brackets will be positive. Like any empirical equation, application of Eq. (31) should be limited to 
the assumed levee geometry that is a sea-side slope of $1 \mathrm{~V}: 4.25 \mathrm{H}$ and a land-side slope of $1 \mathrm{~V}: 3 \mathrm{H}$.

Fig. 9 shows the comparison of overtopping discharge estimated from Eq. (31) and the predicted overtopping discharges on earthen levee using equations of Eurotop manual (2007), Reeve et al. (2008), Hughes and Nadal (2009), and full-scale overtopping experimental results from Pan et al. (2013) and Yuan et al. (2014a). As shown in Fig. 9, the new equation can estimate the overtopping discharge very well as compared with the full-scale overtopping experimental results in Yuan et al. (2014a) and with the Hughes and Nadal's equation (2009). Both equations of Revee et al. (2008) and Eurotop manual (2007) overestimated the overtopping discharges with equations of Revee et al. (2008) showing the greatest difference. The experimental results from Pan et al. (2013) are slightly lower than the estimates of Eq. (31), which may be attributed to the flow leaking between the tested levee and the flume wall mentioned in Pan et al. (2013).

\subsection{Flow parameters on the HPTRM strengthened levee slope}

The hydraulic conditions on the HPTRM strengthened levee slope are complicated during the combined wave overtopping and storm surge overflow. There is no intuitive understanding of distribution of flow parameters along the land-side slope and at the toe

of land-side slope. New empirical equations are available to characterize several 
representative parameters of wave-related unsteady flow on the land-side levee slope, as defined in Hughes and Nadal (2009). The instantaneous flow thickness perpendicular to the levee slope, $d$, is a function of time (Fig. 10). The peak flow thickness for each wave is designated as $h$, and the slope-perpendicular distance between the wave crest and the following wave trough is referred to as $H$. When the land-side slope goes dry between overtopping waves, then $h=H$. For larger values of negative freeboard, the slope usually does not go dry with passage of each wave. For these cases, wave trough flow thickness is positive and $h>H$ (Hughes and Nadal, 2009). Fig. 11 gives an example of time series of flow thickness and flow velocity at the toe of land-side slope for the combined wave overtopping and storm surge overflow with surge height of $0.3 \mathrm{~m}$, energy-based significant wave height of $0.78 \mathrm{~m}$, and peak wave period of $7 \mathrm{~s}$. Unsteadiness and randomness of overtopping events can be seen from this figure.

\subsubsection{Average flow thickness at the land-side slope toe}

The average flow thickness, $d_{m}$, was calculated by averaging the flow thickness at the end of the land-side slope starting with data point $30 \mathrm{~s}$ and continuing to the end of the time series. An average was taken over the last four consecutive cells $(4 \times 0.1 \mathrm{~m}=0.4$ m) to represent the mean flow thickness at the toe of the land-side slope. A correlation was sought between the mean flow thickness and the average overtopping discharge, and 
the results are shown in Fig. 12. These solid line is linear best-fit equation given by the simple empirical expressions as:

$$
\left(\frac{g R_{c}^{3}}{q_{w s}^{2}}\right)^{1 / 3}=91.745\left(\frac{d_{m}}{H_{m 0}}+0.145\right)^{2}-1.941
$$

Equation (32) has a correlation coefficient of 0.96 and a root-mean-square error of 0.073. Hughes and Nadal (2009) provided a more detailed expression of average flow thickness along the land-side slope as a function of land-side slope angle. Application of Eq. (32) is limited to the land-side slope of $1 \mathrm{~V}: 3 \mathrm{H}$. The impact of different land-side slopes is not included in this equation.

Fig. 12 shows the estimates of the average water thickness at the toe given by Hughes and Nadal (2009). The numerical model results are about $37 \%$ smaller than the experimental results for average water thickness. The difference may be related to the different setup for the levees between their flume model and our numerical flume. There was a long and mild berm with the slope of 1:24 after the land-side slope in their flume, while this was not the case in our numerical experiment. The berm can cause the variation of water depth and velocity at the slope toe (Yuan et al. 2014c).

\subsubsection{Time series upcrossing analysis}


The calculated time series of flow thickness at the toe of land-side slope were analyzed by the zero-upcrossing technique to identify the maximum and minimum flow thicknesses for all waves contained between data points $30 \mathrm{~s}$ and $700 \mathrm{~s}$. The characteristic slope-perpendicular wave height parameters $H_{r m s}$ and $H_{1 / 3}$ were determined for each measured time series.

$H_{r m s}$ represents the root-mean-square slope-perpendicular wave height calculated using the statistic maximum and minimum flow thicknesses as shown in Eq. (33).

$H_{r m s}=\sqrt{\frac{1}{n} \sum_{m=1}^{n} H_{m}^{2}}$

where $n$ is the amount of random wave, $H_{m}$ is the slope-perpendicular wave height of the $m^{\text {th }}$ wave. A relationship was sought that expressed $H_{r m s}$ in terms of other parameters that could be specified. The normalized average flow thickness is shown in Fig.13 for various values of the relative freeboard. The solid curve represents the best-fit of a linear function given as

$$
\frac{H_{r m s}}{d_{m}}=2.282 \cdot \exp \left(0.573 \cdot \frac{R_{c}}{H_{m 0}}\right)
$$

This best-fit equation had a correlation coefficient of 0.927 and an RMS percent error of 
0.056. Surge height, $R_{c}$, should be entered as a negative number and the equation should not be applied for cases where $R_{\mathrm{c}} \geq 0$. Compared with the estimates by Hughes and Nadal (2009) as shown in Fig. 13, the numerical results are smaller because of increased roughness effects due to the grass cover.

Time-domain significant slope-perpendicular wave height parameter, $H_{1 / 3}$, was determined for each trial, which could be calculated by

$$
H_{1 / 3}=\frac{3}{n} \sum_{m=1}^{n / 3} H_{m}
$$

A relationship was sought that expressed $H_{1 / 3}$ in terms of other parameters that could be specified. The significant slope-perpendicular wave height parameter is shown in Fig. 14a for various values of root-mean-square slope-perpendicular wave height. The solid curve represents the best-fit of a linear function given as

$$
H_{1 / 3}=1.353 H_{r m s}
$$

This best-fit equation had a correlation coefficient of 0.999 and an RMS percent error of 0.013 . The corresponding peak wave flow thickness, $h_{r m s}$ and $h_{1 / 3}$, were also determined from the calculated time series. 


$$
\begin{aligned}
& h_{r m s}=\sqrt{\frac{1}{n} \sum_{m=1}^{n} h_{m}^{2}} \\
& h_{1 / 3}=\frac{3}{n} \sum_{m=1}^{n / 3} h_{m}
\end{aligned}
$$

where $h_{m}$ is the peak wave flow thickness of the $m^{\text {th }}$ wave. These values were obtained by considering only the wave peaks and not the troughs. Figs. $13 \mathrm{~b}$ and $13 \mathrm{c}$ show the two representative flow thickness parameters as a function of the wave height parameter $H_{r m s}$.

The solid lines shown in the plots of Figs. $13 \mathrm{~b}$ and $13 \mathrm{c}$ are the best-fits to the data given by the following empirical equations:

$h_{r m s}=1.0813 \cdot H_{r m s}$

$h_{1 / 3}=1.4202 \cdot H_{r m s}$

The correlation coefficients for Eqs. (39) and (40) were 0.999, and the corresponding RMS errors were 0.011 and 0.010, respectively. Note that Eqs. (39) and (40) are only appropriate for combined wave overtopping and storm surge overflow.

As shown in Fig. 16, the numerical results of ratios between these wave height parameters are almost the same as the estimates by Hughes and Nadal (2009). Although 
the wave height is resisted by the long and rough slope, the shape of waves and the basic characteristics related to the ratio of waves heights at the slope toe do not change.

4.4.3 Estimation of wave front velocity on the land-side slope

Hughes and Nadal (2009) estimated the speed of the wave front by using the time it took the wave front to move from one pressure gauge to the next. The same method was applied here to estimate the wave front velocity on the land-side slope. Fig. 15 shows a portion of the flow thickness time series at the beginning of the land-side slope (solid curve) that has been time-shifted based on the equivalent time series from the toe of the land-side slope (dotted curve). In this case, the shift was $0.6 \mathrm{~s}$ over a down-slope distance of $4.5 \mathrm{~m}$. Therefore, a rough estimate of the wave front velocity is $7.5 \mathrm{~m} / \mathrm{s}$. This approximate wave front velocity represents an average value along the land-side slope. In fact, the flow might still be accelerating over this range. Nevertheless, the matching of shifted time series would seem to indicate that the waves have a nearly constant form as they propagate down the slope.

Fig. 16 shows the estimated wave front velocity as a function of the $H_{r m s}$. The discrete jumps in the velocity are attributed to subjective judgment of superposition of two time series. A similar phenomenon was also observed in Hughes and Nadal (2009). The straight line shown on Fig. 16 is the best-fit given by the simple equation 
$v_{m}=4.486 \exp \left[0.377\left(g H_{r m s}\right)^{1 / 2}\right]$, for $R_{c} \geq 0.3 \mathrm{~m}$ and $H_{m 0} \geq 0.381 \mathrm{~m}$

where $v_{w}$ is the wave front velocity. This best-fit had a correlation coefficient of 0.976 and an RMS percent error of 0.366. The coefficient in Eq. (41) is constant for this particular data set; but it may be a function of slope angle and surface roughness.

\section{Conclusions}

The 3D hydrodynamic numerical model, POM-WAD, was used to investigate the hydrodynamics of a HPTRM strengthened levee under combined wave overtopping and storm surge turbulent overflow. A combination of 41 hydraulic cases including surge levels of $0.2 \mathrm{~m}$ to $1.2 \mathrm{~m}$, significant wave height of $0.2 \mathrm{~m}$ to $1.8 \mathrm{~m}$, and peak wave periods of $7 \mathrm{~s}$ to $10 \mathrm{~s}$ were studied. After the model was calibrated with the deflected plant height and full-scale overtopping experimental results, the overtopping discharge, flow thickness, RMS wave height, and wave front velocity were determined.

An empirical equation was developed that expressed the average overtopping discharge per unit length along the levee as a function of negative freeboard and incident significant wave height. The new equation fits well with overtopping experimental data, and gives lower overtopping rates than previous numerical solutions. 
Several parameters of the supercritical unsteady flow on the land-side levee slope were examined, and equations were developed based on the time series of flow thickness at the toe of land-side levee slope. A new equation for average flow thickness at the slope toe was also presented. Using the zero-upcrossing technique, characteristic slope-perpendicular wave height and peak wave flow thickness on the land-side slope, including $H_{r m s}, H_{1 / 3}, h_{r m s}$ and $h_{1 / 3}$ were determined. The root-mean-square wave height, $H_{r m s}$, at the land-side slope toe was expressed as a function of the mean flow thickness, $d_{m}$, and the relative freeboard, $R_{d} / H_{m 0}$. Other characteristic wave height and peak wave flow thickness were all given as a simple linear function of the root-mean-square slope-perpendicular wave height, $H_{r m s}$.

Time shifted technique was applied to estimate the wave front velocity on the land-side slope. The amount of time shift was used to estimate the wave front velocity, and the velocity was correlated to $H_{r m s}$. The applicability of the equations developed in this study for levee slopes other than $1 \mathrm{~V}: 3 \mathrm{H}$ is uncertain, and these equations may give incorrect estimates where slope surface roughness is not similar to HPTRM.

\section{Acknowledgment}

This research was funded by the Department of Homeland Security-sponsored Southeast Region Research Initiative (SERRI) at the Department of Energy's Oak Ridge 
National Laboratory. It was also funded by China National Funds for Distinguished Young Scientists (51125034) and National Science Foundation of China (51239003, 51279046, 50879019), and Ph.D. Discipline Foundation of Ministry of Education of China (200802940001). The opinions and conclusions described in this paper are solely those of the authors and do not necessarily reflect the opinions or policies of the sponsors.

\section{References}

ASCE Hurricane Katrina External Review Panel, 2007. The New Orleans Hurricane Protection System: What Went Wrong and Why. American Society of Civil Engineers, Reston, Virginia. 92 pp.

Blumberg, A.F. and Mellor, G.L., 1987. A description of a three-dimensional coastal ocean circulation model. Coastal and estuarine sciences: Volume 4, N. Heaps, ed., American Geophysical Union, Washington, D.C., 1-16.

Ezer, T., Oey, L-Y., Lee, H-C., and W. Sturges, 2003. The variability of currents in the Yucatan Channel: Analysis of results from a numerical ocean model. Journal of Geophysical Research, Vol. 108, No. C1, pp. 3012, 10.1029/2002JC001509.

Ezer, T., Hobbs, R. and Oey, L.-Y., 2008. On the movement of Beluga whales in Cook Inlet, Alaska: Simulations of tidal and environmental impacts using a hydrodynamic inundation model. Oceanography, Vol. 21, No. 4, pp. 14-23. 
Goda, 1999. A comparative review on the functional forms of directional wave spectrum. Coastal Engineering Journal, Vol. 41, No. 1, pp. 1-20.

Goodrum, R. 2011. A Comparison of sustainability for three levee armoring alternatives. Optimizing Sustainability Using Geosynthetics, the 24th Annual GRI conference Proceedings, edited by Koerner, G.R., Koerner, R. M., Ashley, M. V., Hsuan, G. Y., and Koerner J., R., Dallas, Texas, Geosynthetics Research Institute, pp. 40-47.

Hanson, G. J., Cook, K. R., and Hunt, S. L., 2005. Physical modeling of overtopping erosion and breach formation of cohesive embankments, Transactions of the ASAE Vol. 48, No. 5, pp. 1783-1794.

Hasselmann, K., 1973. Measurement of Wind-waves and Swell Decay during the Joint North Sea Wave Project (JONSWAP). Deutsches Hydrographisches Institute, Hamburg, 96p.

Henderson, F.M., 1966. Open Channel Flow. MacMillan Company, New York, USA, $544 \mathrm{p}$.

Hu, K., Mingham, C.G., Causon, D.M., 2000. Numerical simulation of wave overtopping of coastal structure using the non-linear shallow water equation. Coast Engineering Vol. 41, pp. 433-465.

Hubbard, M.E., and Dodd, N., 2002. A 2D numerical model of wave run-up and overtopping. Coastal Engineering, Vol. 47, pp. 1-26.

Hughes, S.A. and Nadal, N.C., 2009. Laboratory study of combined wave overtopping 
and storm surge overflow of a levee. Coastal Engineering, Vol. 56, pp. 244-259.

Lu, Q.M. and Wai, W.H., 1998. An Efficient Operator Splitting Scheme for Three-dimensional Hydrodynamic Computations, International Journal for Numerical Methods in Fluids, Vol. 26, pp. 771-789.

Mellor, G.L., and Yamada, T., 1982. Development of A Turbulence Closure Model for Geophysical Fluid Problems, Reviews of Geophysics and Space Physics, Vol. 20, No. 4, pp. 851-85.

Mellor, G.L., Oey, L.Y. and Ezer, T., 1998. Sigma Coordinate Pressure Gradient Errors and the Seamount Problem. Journal of Atmospheric and Oceanic Technology, Vol. 15 , pp. $1122-1131$

Oey, L-Y., Lee, H-C., and Schmitz, W. J., 2003: Effects of winds and Caribbean eddies on the frequency of Loop Current eddy shedding: A numerical model study. Journal Geophysical Research, Vol. 108, No. C10, pp. 3324, doi:10.1029/ 2002JC001698.

Oey L.Y., 2005. A wetting and drying scheme for POM. Ocean Modeling, Vol. 9, pp. $133-150$.

Pan, Y., Li, L., Amini, F., and Kuang, C., 2013. Full scale HPTRM strengthened levee testing under combined wave and surge overtopping conditions: Overtopping hydraulics, shear stress and erosion analysis. Journal of Coastal Research, Vol. 29, No. 1, pp. 182-200. 
Pullen, T., Allsop, N.W.H., Bruce, T., Kortenhaus, A., Schüttrumpf, H., and van der Meer, J.W., 2007. EurOtop: Wave overtopping of sea defences and related structures: Assessment Manual.

Rao, X., Li, L, Amini, F. and Tang, H, 2012. Numerical study of combined wave and surge overtopping over RCC strengthened levee system using smoothed particle hydrodynamics method, Ocean Engineering, Vol. 54, pp. 101-109.

Reeve, D.E., Soliman, A., and Lin, P.Z., 2008. Numerical study of combined overflow and wave overtopping over a smooth impermeable seawall. Coastal Engineering, Vol. 55, pp. $155-166$.

Schüttrumpf, H., Möller, J., Oumeraci, H., Grüne, J., and Weissmann, R., 2001. Effects of natural sea states on wave overtopping of seadikes. Proceedings of the 4th International Symposium Waves 2001, Ocean Wave Measurement and Analysis, ASCE, Vol. 2, pp. 1565-1574.

Shiach, J., Mingham, C.G., Ingram, D.M., Causon, D.M., Bruce, T., Pearson, J., Allsop, N.W.H., 2004. Extend shallow water prediction of overtopping. Proc. of 29th international conference in Coastal Engineering, Lisbon, Portugal, pp. 4443-4455.

Sills, G. L., Vroman, N. D., Wahl, R. E., and Schwanz, N. T., 2008. Overview of New Orleans levee failures: Lessons learned and their impact on national levee design and assessment. Journal of Geotechnical and Geoenvironmental Engineering, Vol. 134, pp.556-565. 
Stephan, U. and Gutknecht, D., 2002. Hydraulic resistance of submerged flexible vegetable. Journal of Hydrology, Vol. 269, pp. 27-43.

van der Meer, J.W., Schrijver, R., Hardeman, B., van Hoven, A., Verheij, H., and Steendam, G. J., 2009, Guidance on erosion resistance of inner slopes of dikes from three years of testing with the Wave Overtopping Simulator. Proc. ICE, Coasts, Marine Structures and Breakwaters 2009, Edinburgh, UK, ), pp. 1-15.

Yuan, S., L. Li, F. Amini, H. Tang, 2014a, Turbulence measurement of combined wave and surge overtopping over a full scale HPTRM strengthened levee, Journal of Waterways, Coastal and Ocean Engineering, Vol. 140, No. 4, pp. 04014014.

Yuan, S., Li, L., Amini, F., and Tang, H., 2014b, Numerical study of turbulence and erosion of an HPTRM strengthened levee under combined storm surge overflow and wave overtopping, Journal of Coastal Research, Vol. 30, No. 1, pp. 142-157.

Yuan, S., Li, L., Amini, F., and Tang, H., 2014c, Sensitivity of combined turbulent wave overtopping and storm surge overflow response to variations in levee geometry, Journal of Coastal Research, accepted, in print. 
(a)
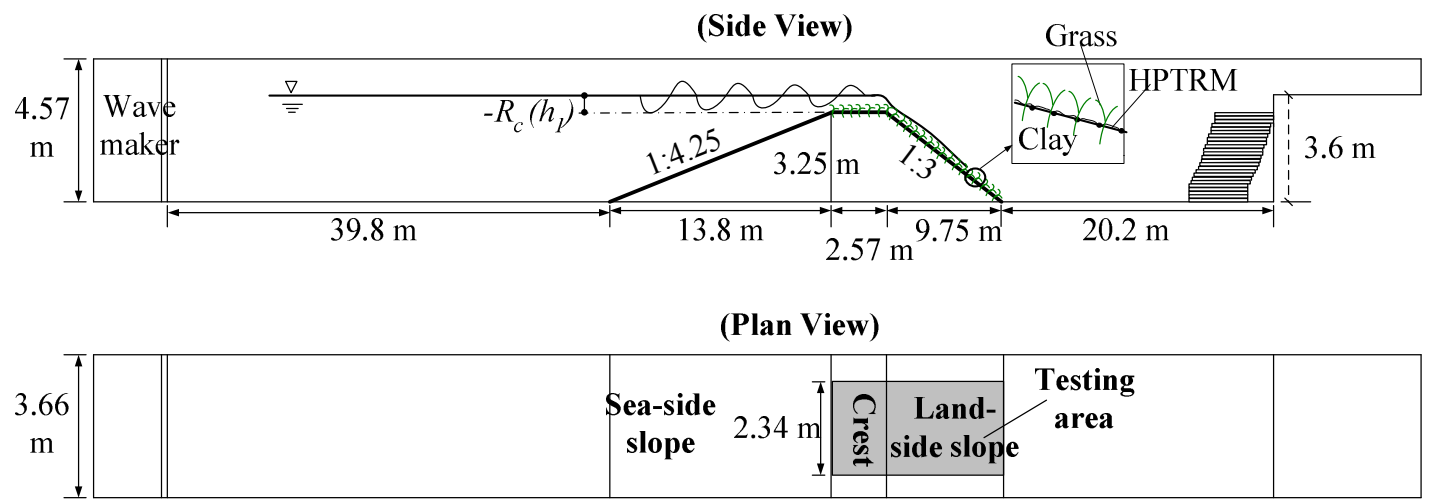

(b)
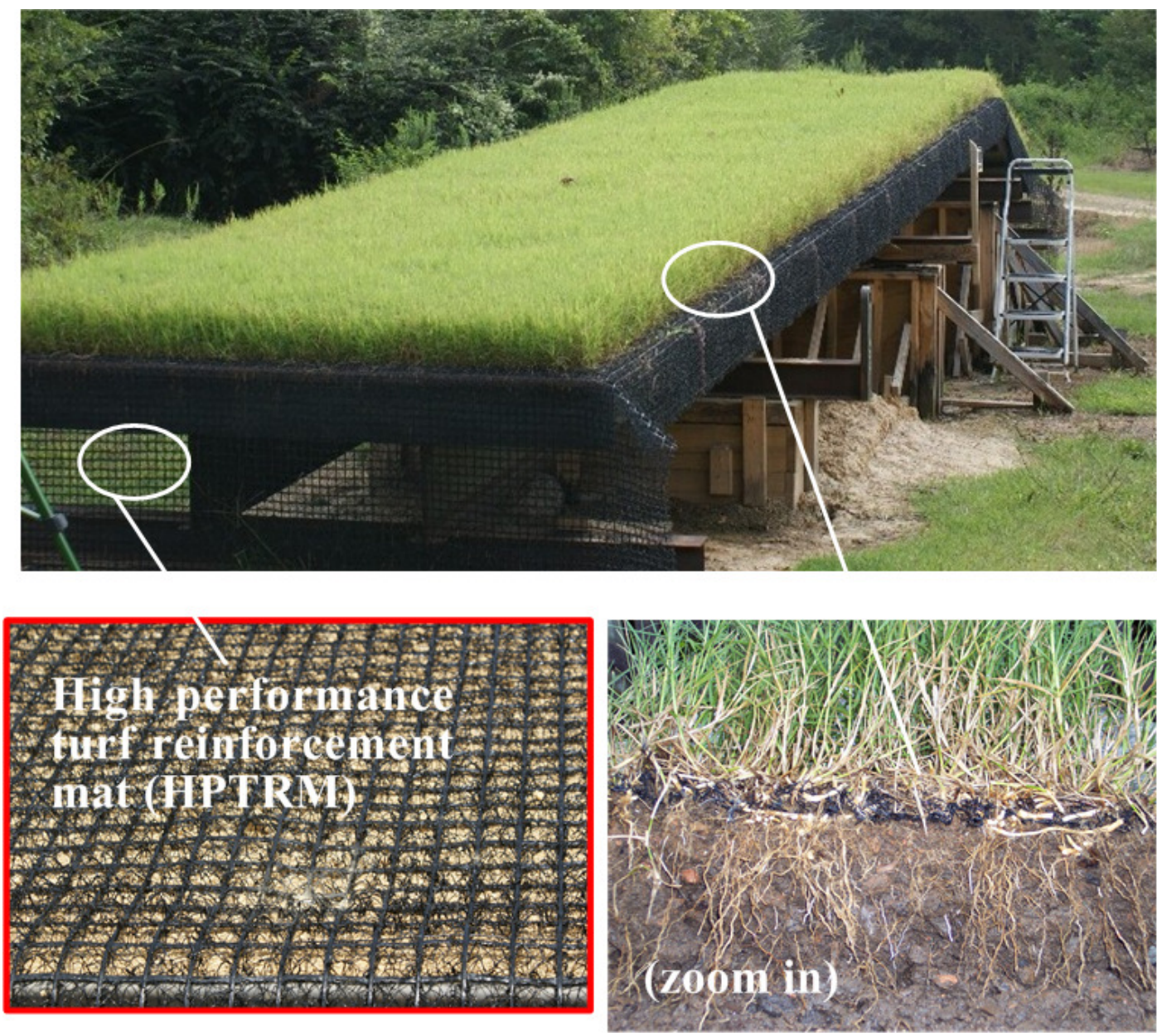

Fig. 1. Profile view of the large wave flume and location of levee embankment (a), and photo of HPTRM system built for the tests. 


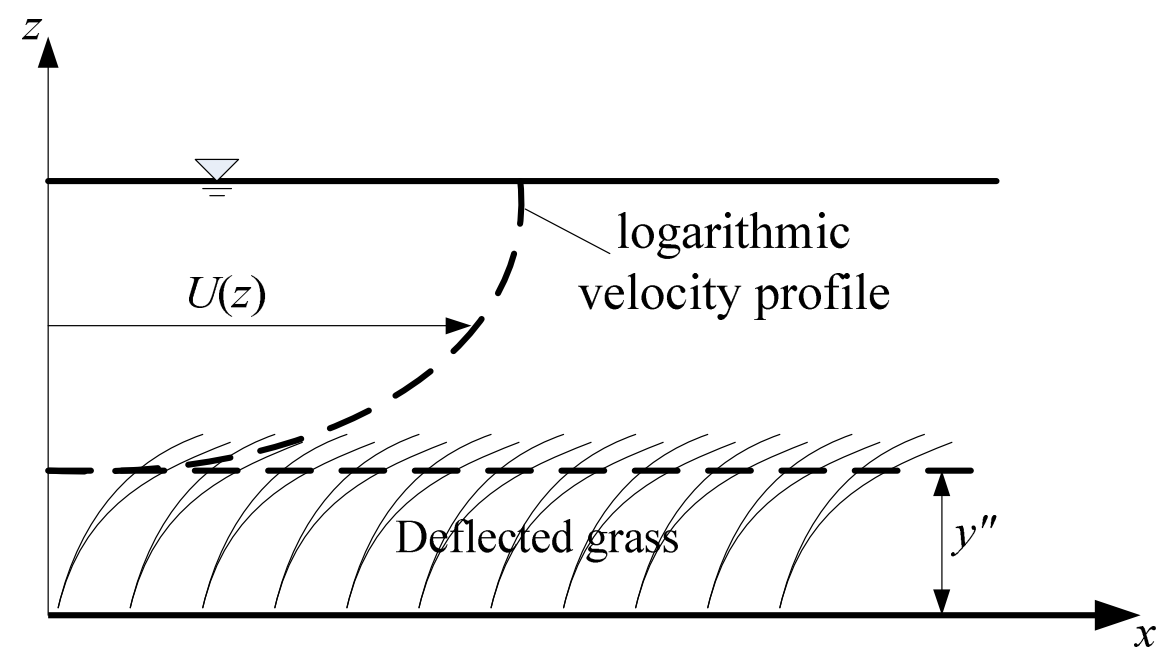

Fig. 2. Vertical velocity profile above grass. 


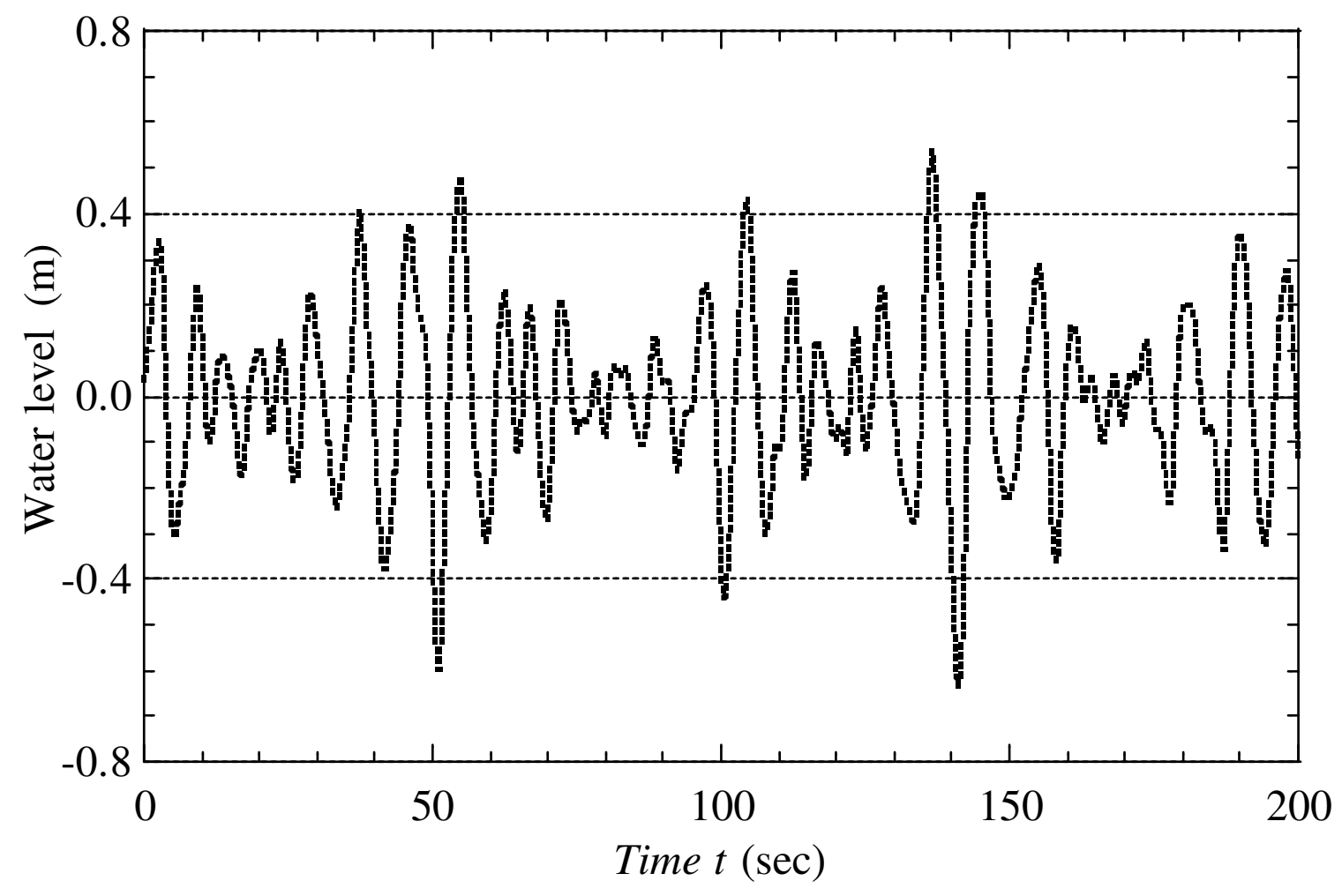

Fig. 3. Example of generated random wave (JONSWAP spectrum, $H_{m 0}=0.778 \mathrm{~m}, T_{p}=$ $7.0 \mathrm{~s}$, and mean sea level $=0$ ). 
a

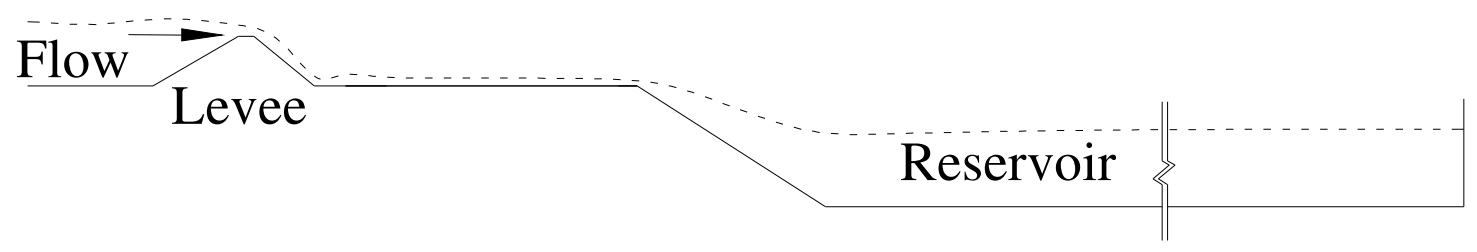

b

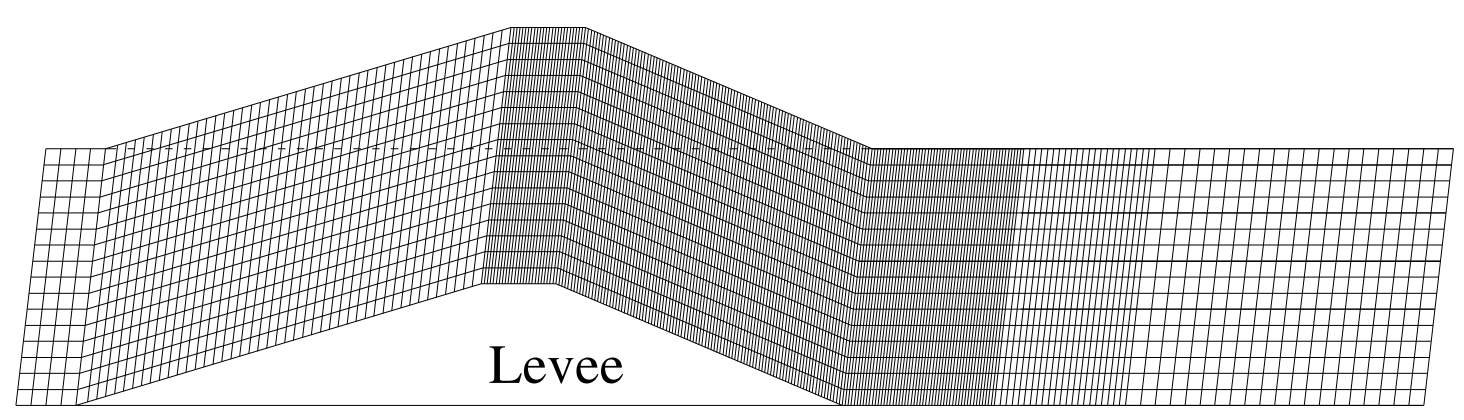

c

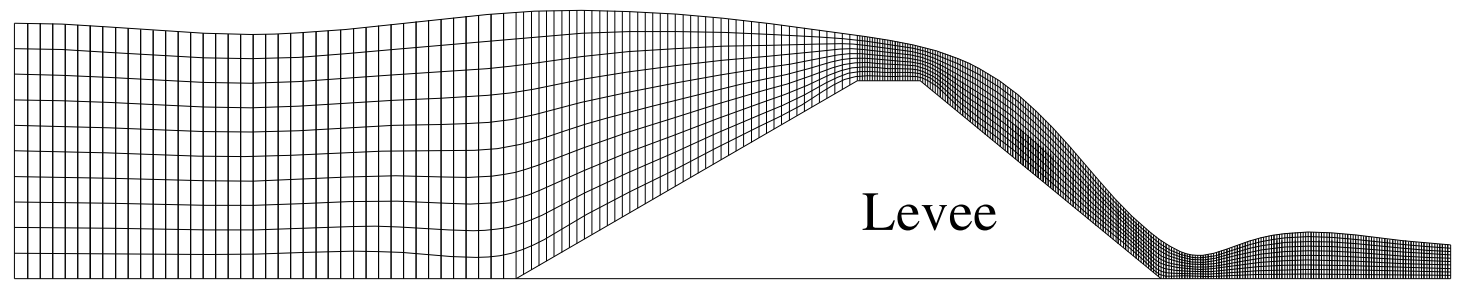

Fig. 4. Profile of levee embankment and downstream reservoir (a), oblique view of amplified horizontal orthogonal grid (b) and amplified vertical sigma grid (c). 

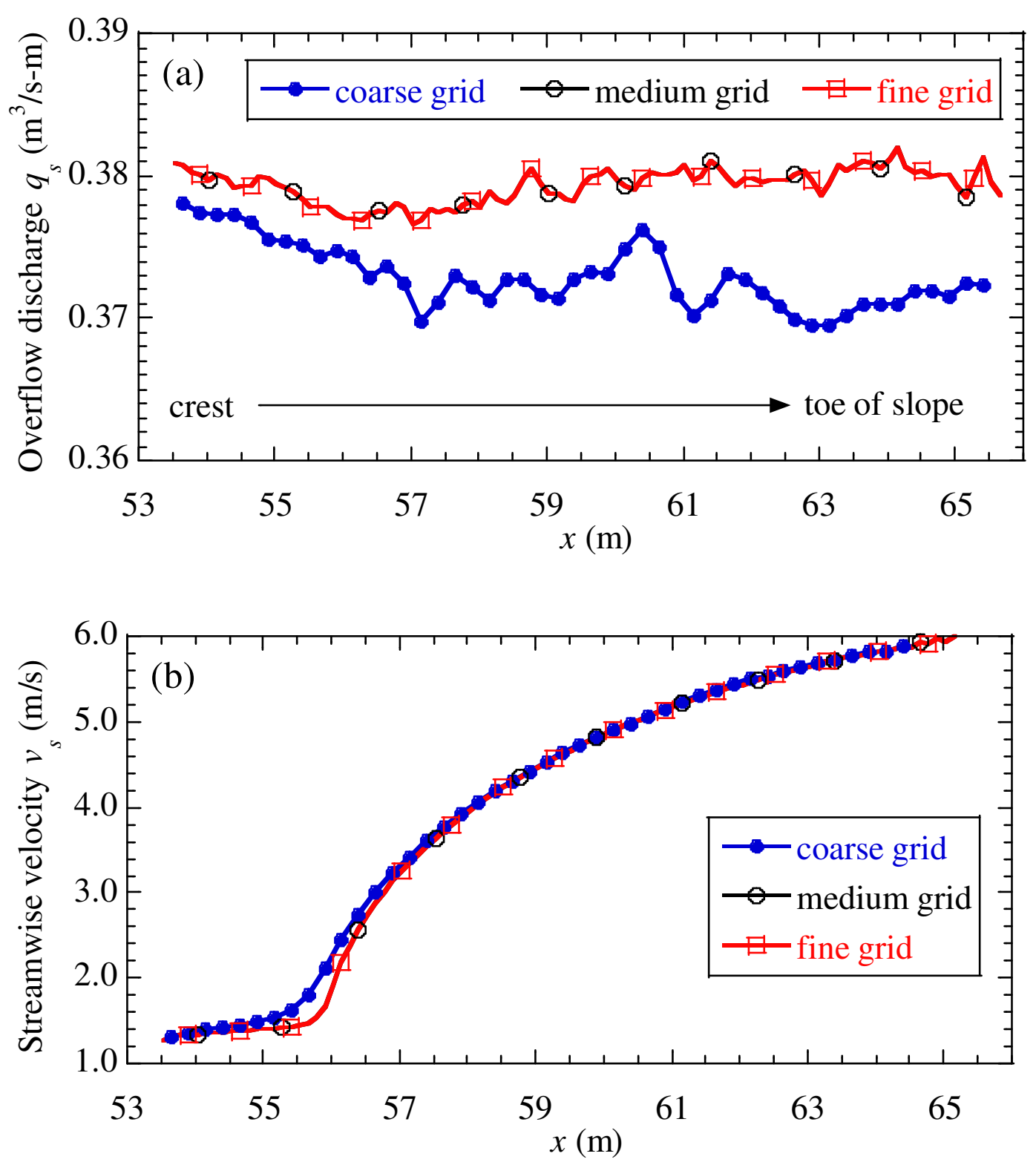

Fig. 5. Comparison of predicted steady overflow discharge (a), and streamwise velocity (b) from the beginning of the crest to the toe of the land-side slope in three grids (zero value of $x$ was placed at the wave maker) for the storm surge overflow with an inflow surge depth of $0.3 \mathrm{~m}$. 


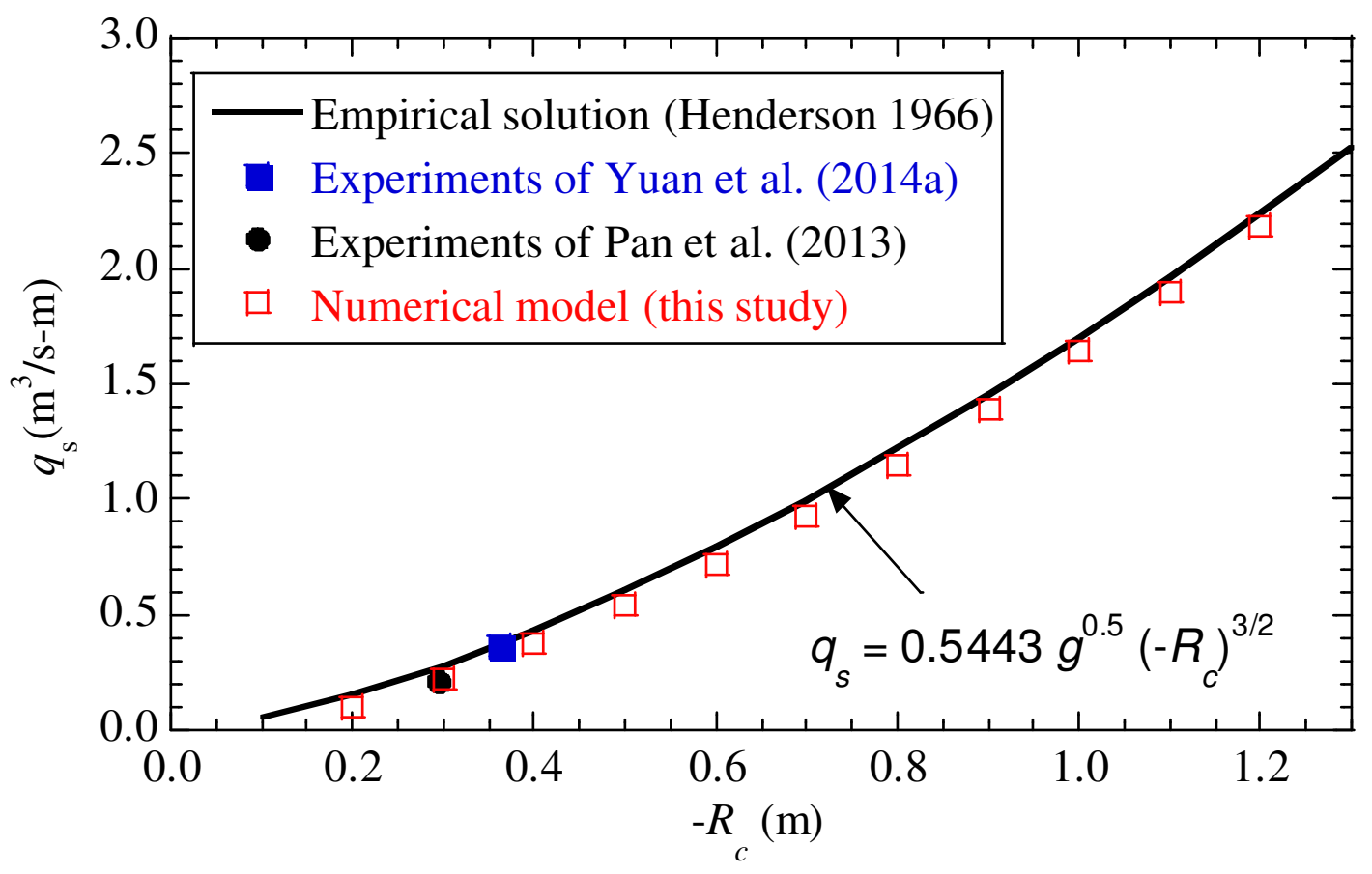

Fig. 6. Estimation of steady overflow discharge using the modeling study, equation of Henderson (1966), and full-scale overtopping tests (Pan et al, 2013, Yuan et al, 2014a). 

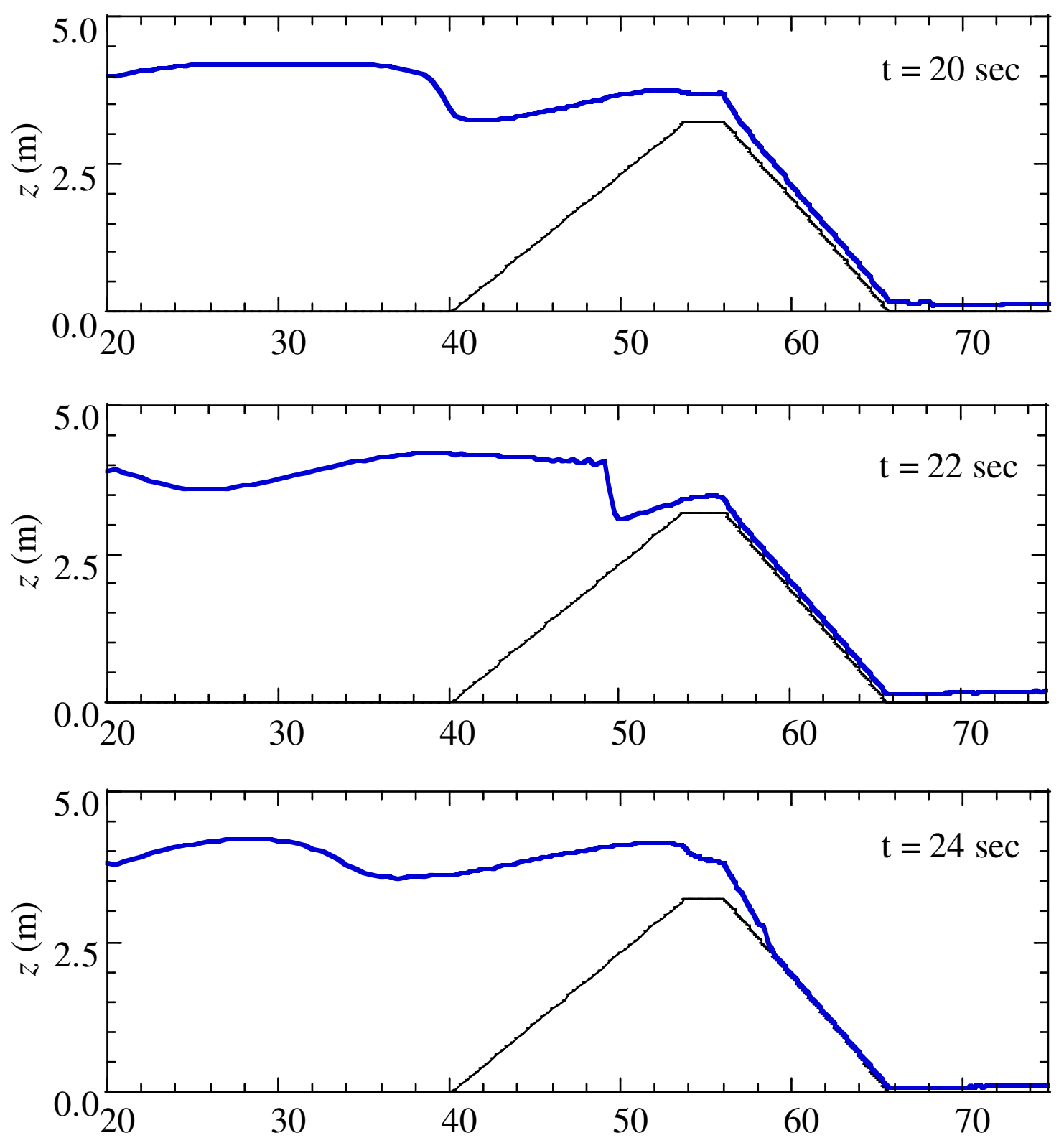

Fig. 7. Instantaneous combined wave/surge overtopping process for one average period (Freeboard $-R_{c}=0.6 \mathrm{~m}$, energy-based significant wave height $H_{m 0}=0.8 \mathrm{~m}$, peak wave period $T_{p}=7 \mathrm{~s}$ ). 


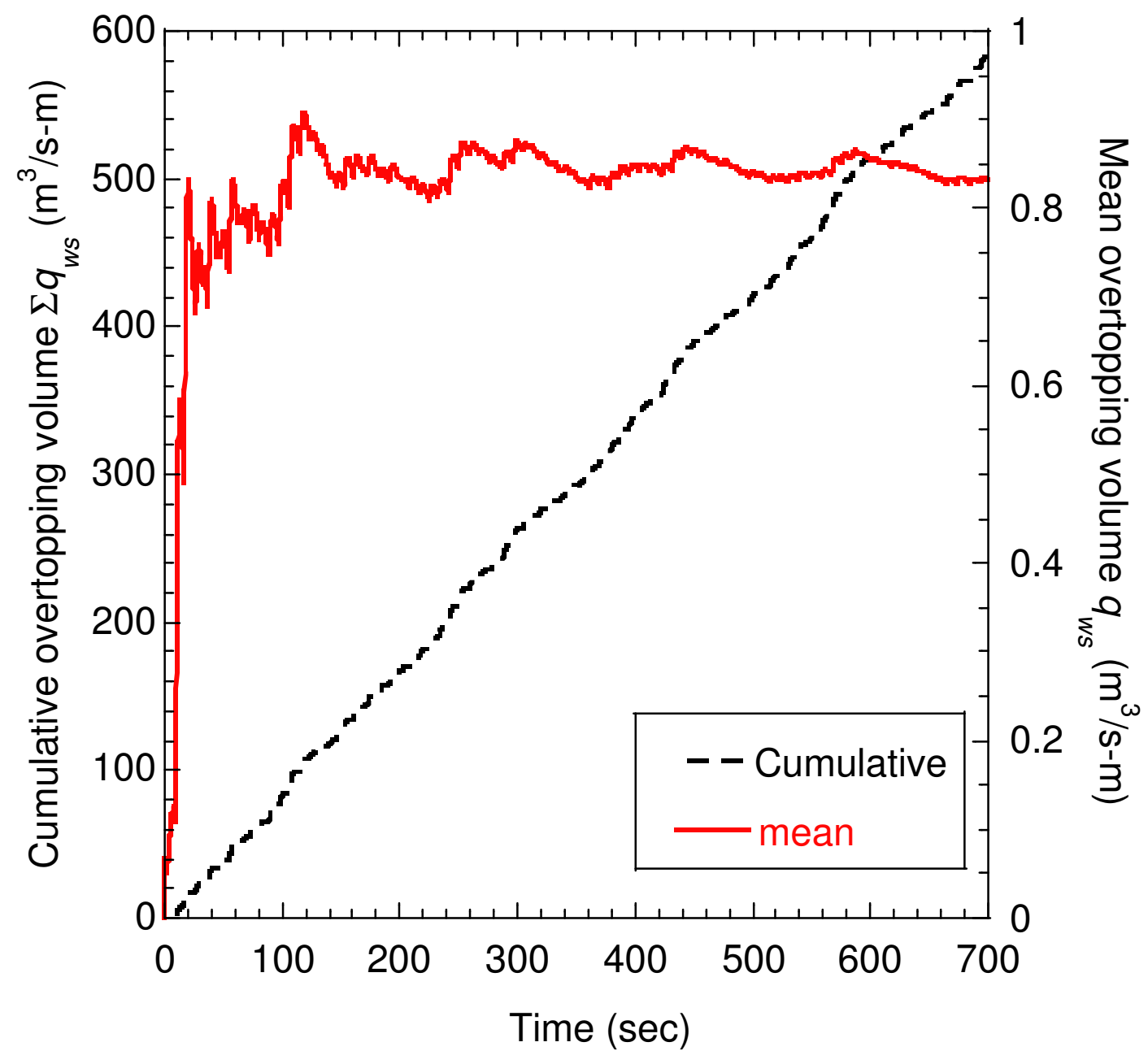

Fig. 8. Time history of cumulative and mean overtopping volumes for combined wave overtopping and storm surge overflow at the toe of land-side slope. $\left(-R_{c}=0.3 \mathrm{~m}, H_{m 0}=\right.$ $0.6 \mathrm{~m}$, and $\left.T_{p}=7 \mathrm{~s}\right)$. 


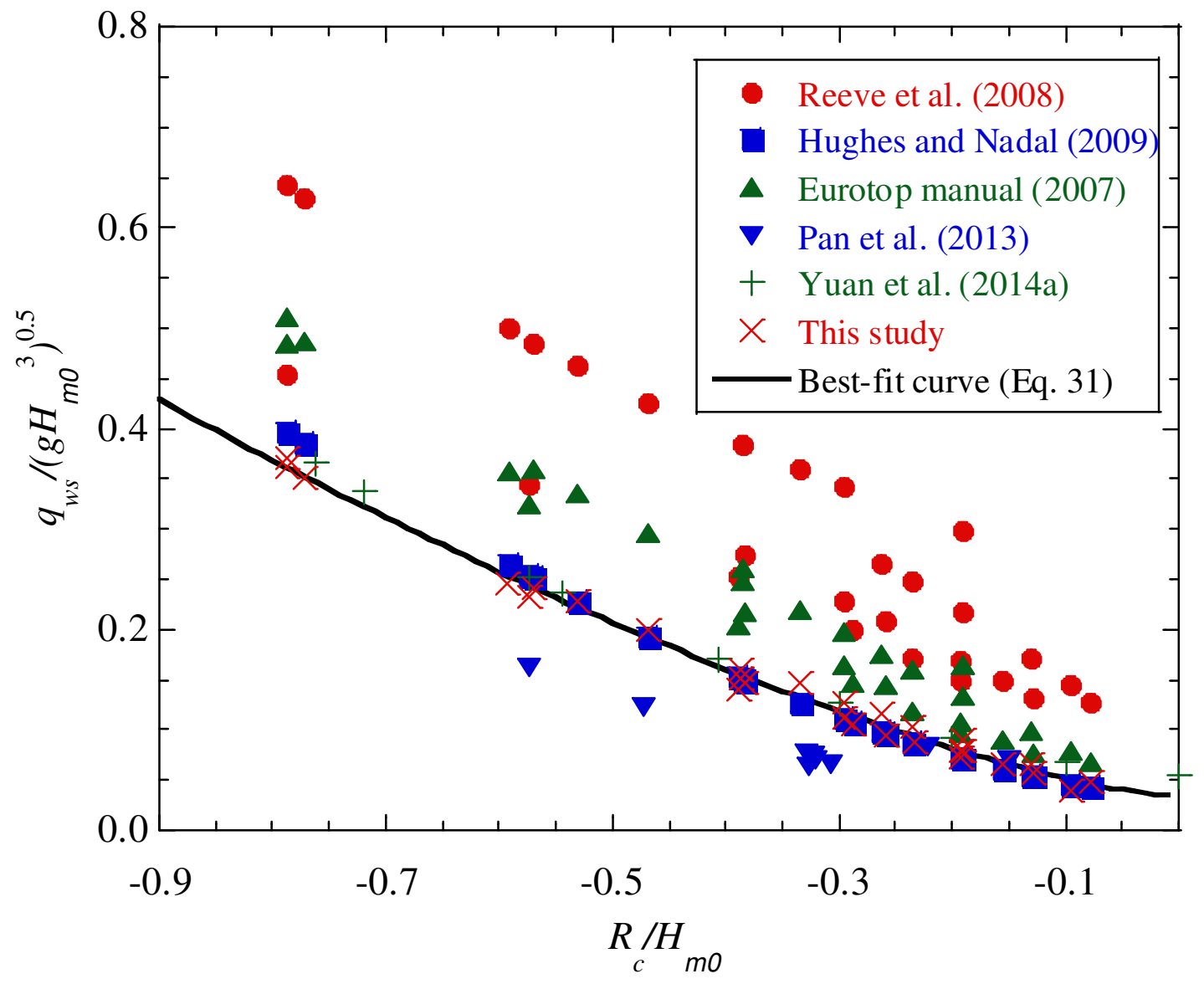

Fig. 9. Comparison of overtopping discharge estimated from the modeling study with the predicted overtopping discharges on earthen levee using equations of Eurotop manual (2007), Reeve et al. (2008), and Hughes and Nadal (2009), and full-scale overtopping results from Pan et al. (2013) and Yuan et al. (2014a). 


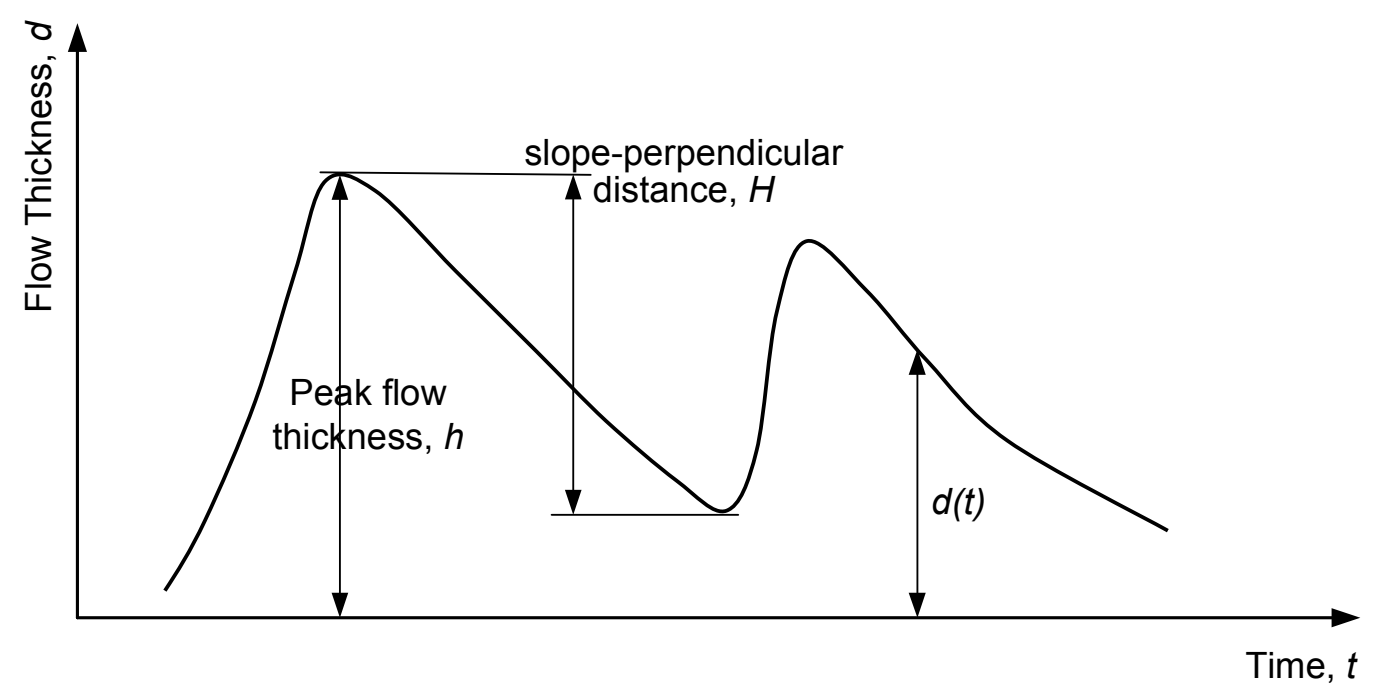

Fig. 10. Definition sketch of flow thickness parameters on the land-side slope. $d(t)$ is instantaneous flow thickness perpendicular to the levee slope, $h$ is peak flow thickness for each wave, and $H$ is slope-perpendicular distance between the wave crest and the following wave trough (After Hughes and Nadal (2009)). 

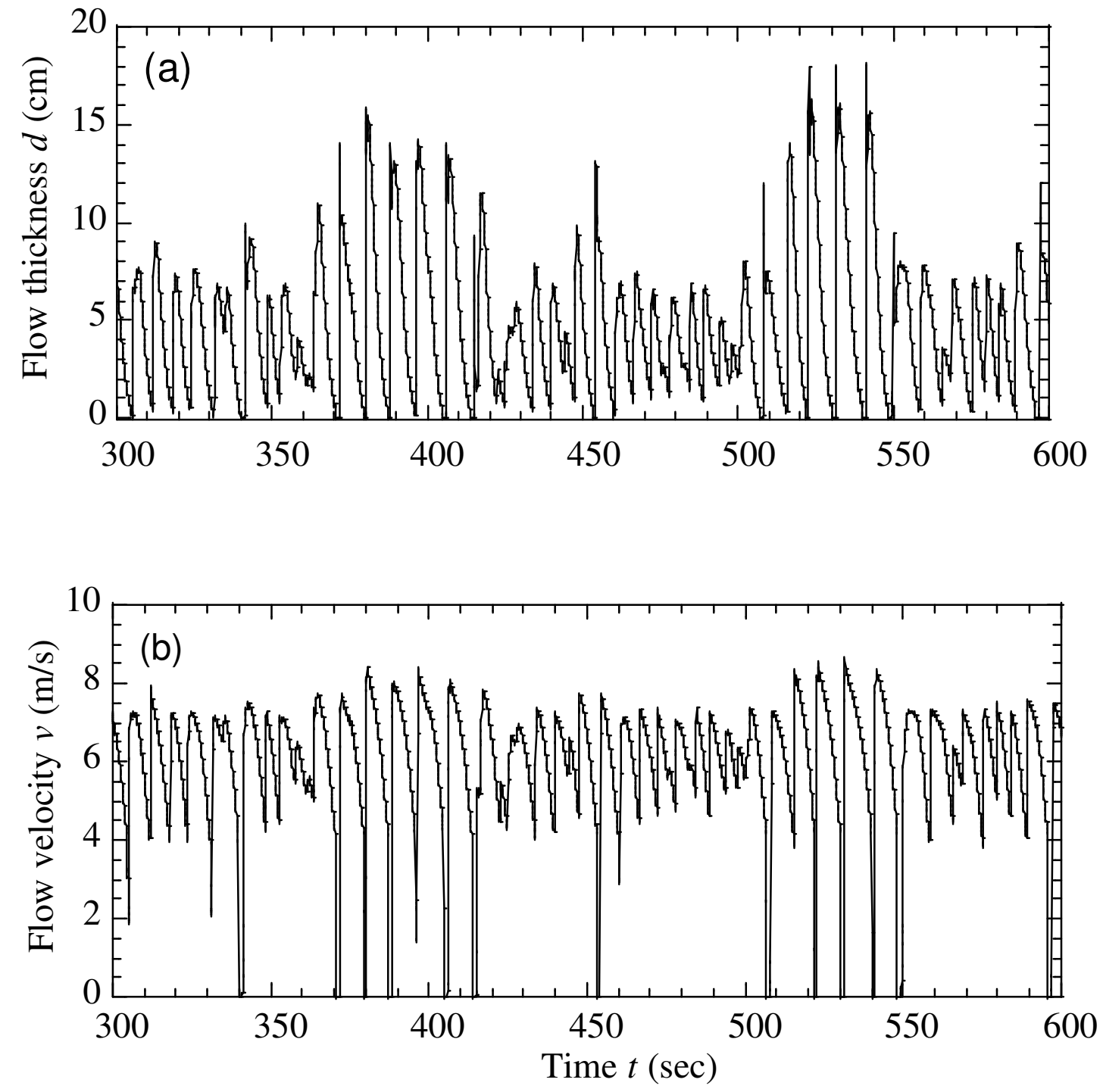

Fig. 11. Time history of flow thickness (a), and flow velocity (b) at the toe of land-side slope $\left(-R_{c}=0.3 \mathrm{~m}, H_{m 0}=0.78 \mathrm{~m}\right.$, and $\left.T_{p}=7 \mathrm{~s}\right)$. 


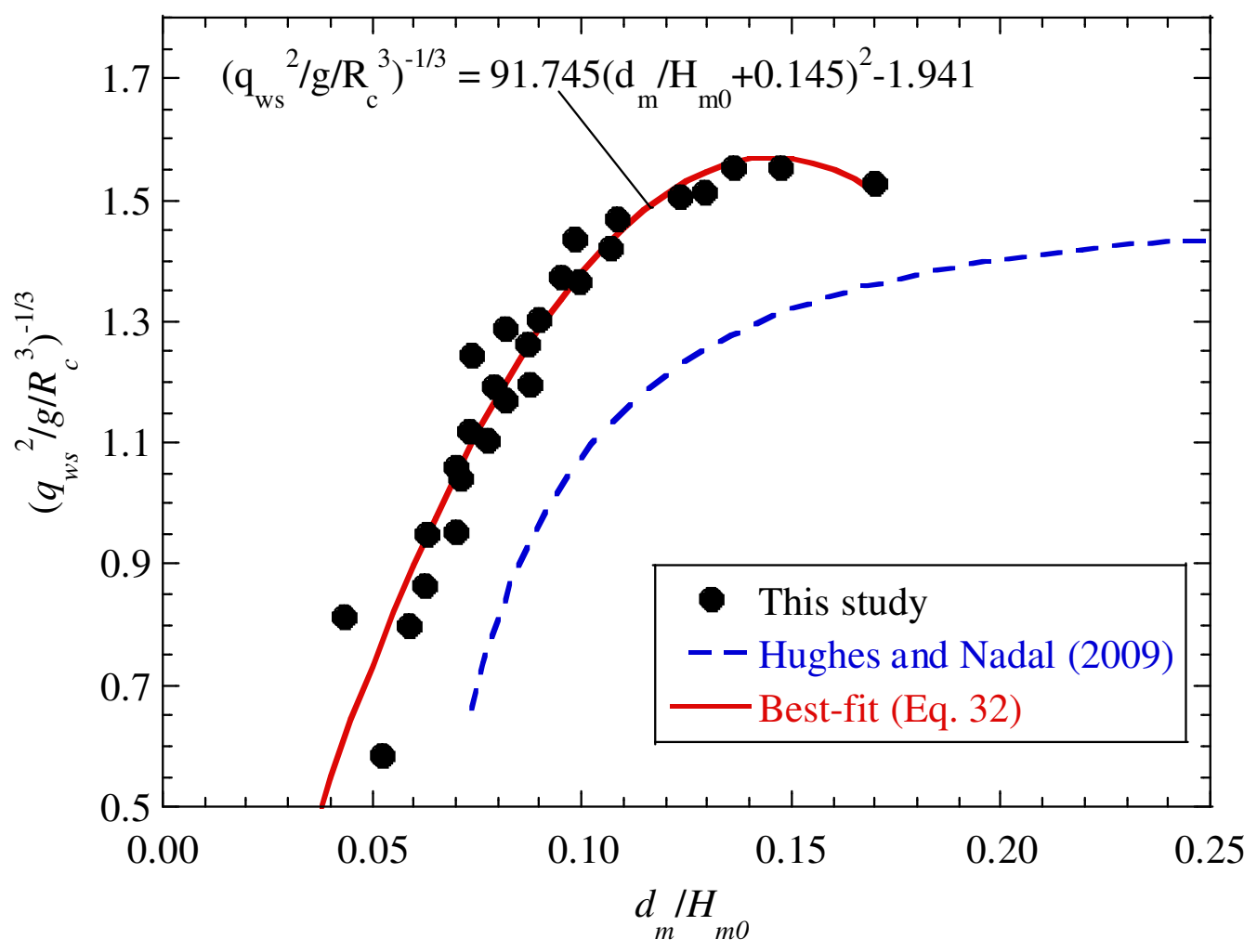

Fig. 12. Mean flow thickness at the toe of the land-side slope as a function of average overtopping discharge. 


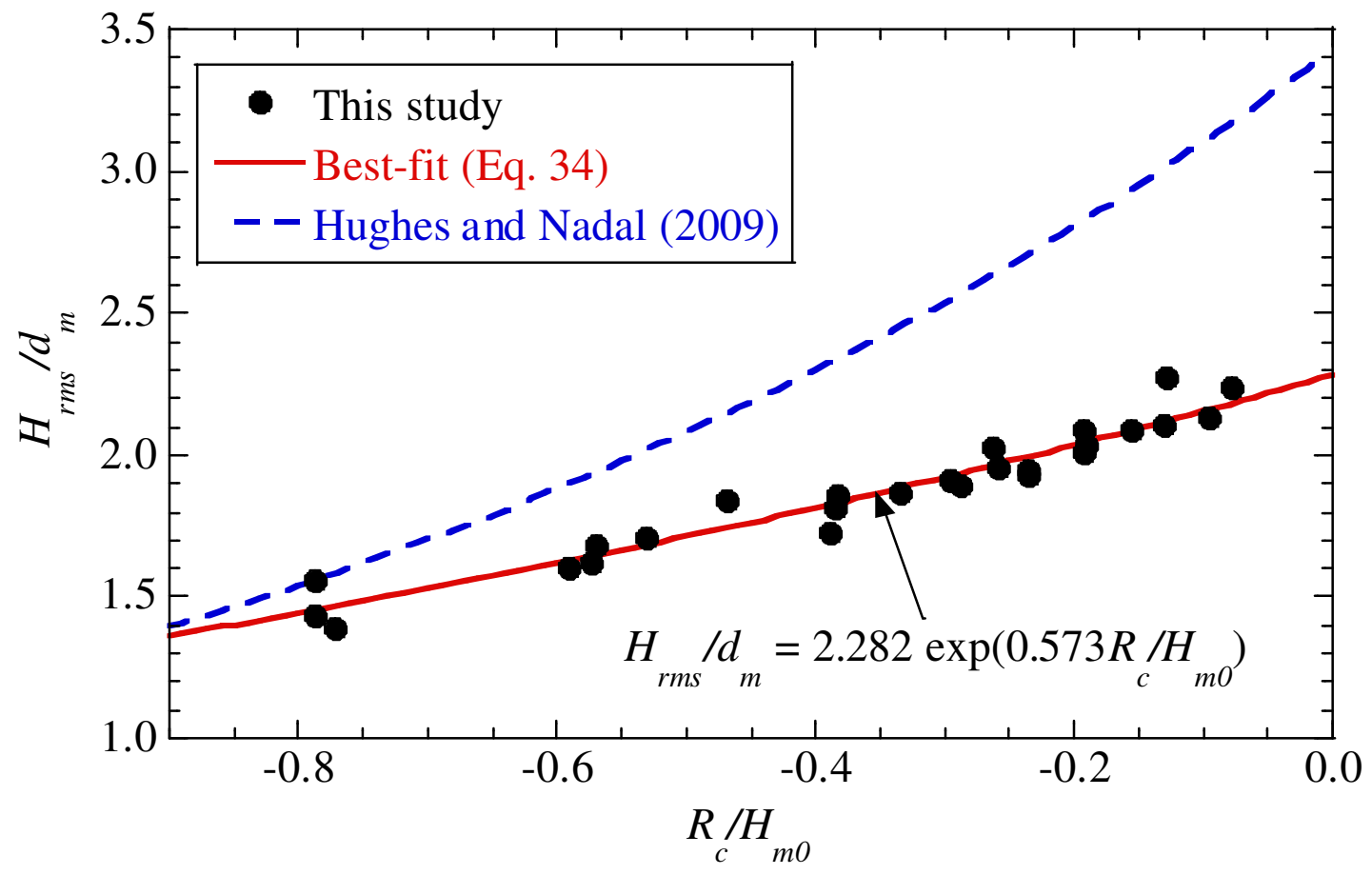

Fig. 13. Estimation of $H_{r m s} / d_{m}$ on the land-side slope as a function of relative freeboard $R_{c} / H_{m 0}$. 

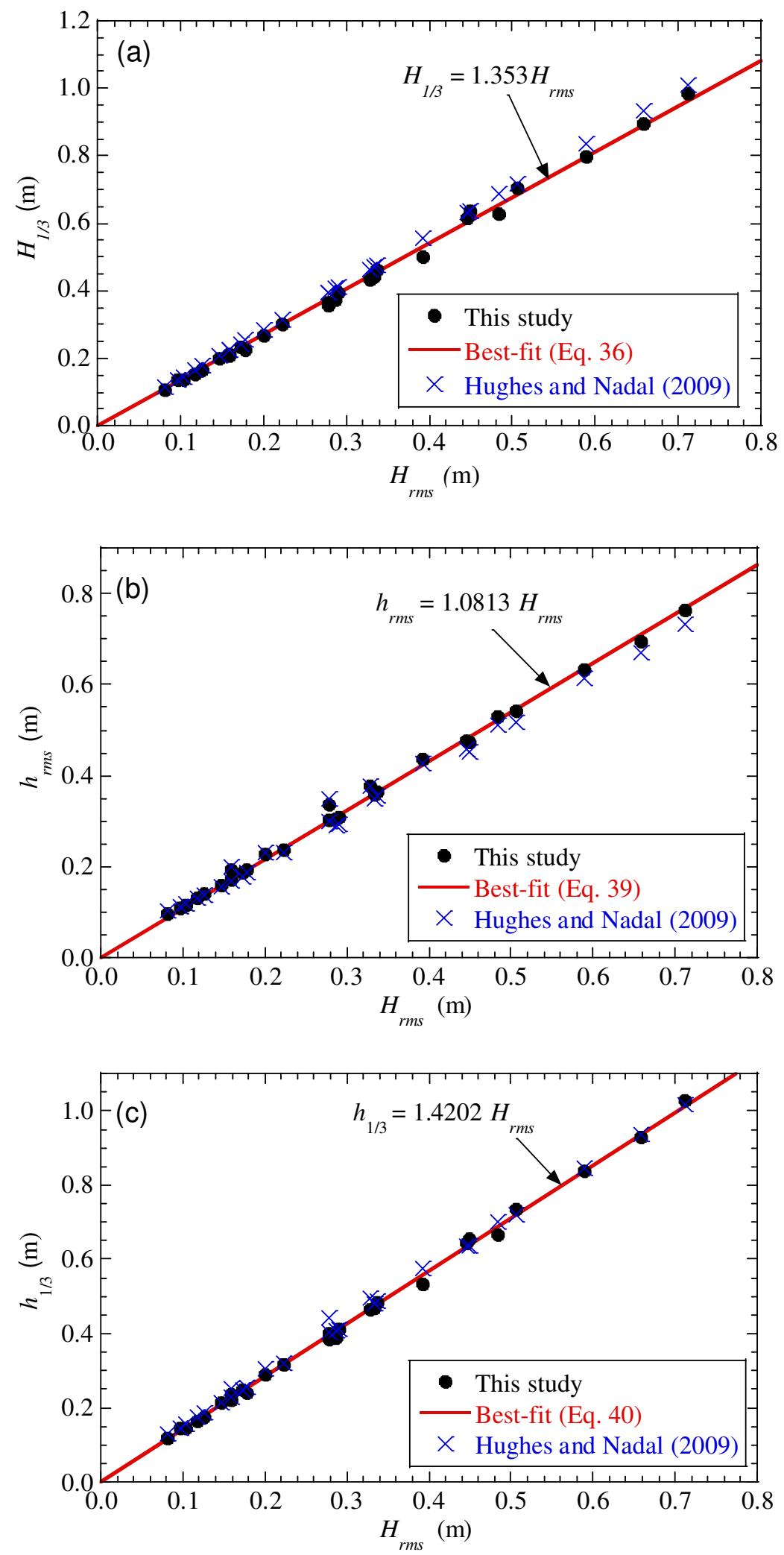
Fig. 14. Time series upcrossing analysis: (a) prediction of land-side slope toe significant slope-perpendicular wave height parameter $H_{1 / 3}$, (b) representative flow thickness $h_{\text {rms }}$, and (c) representative flow thickness $h_{1 / 3}$ as a function of the wave height parameter $H_{r m s}$.

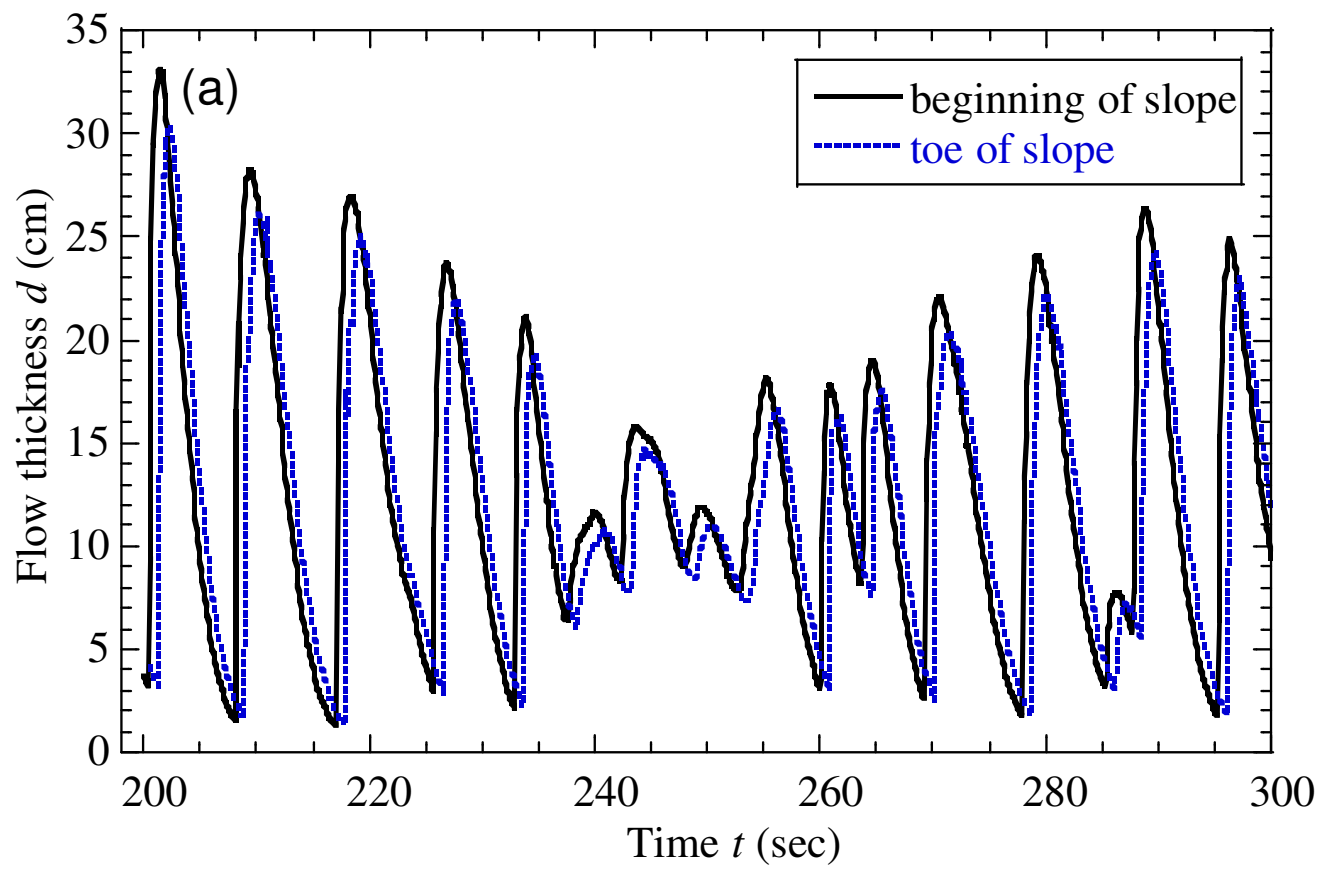




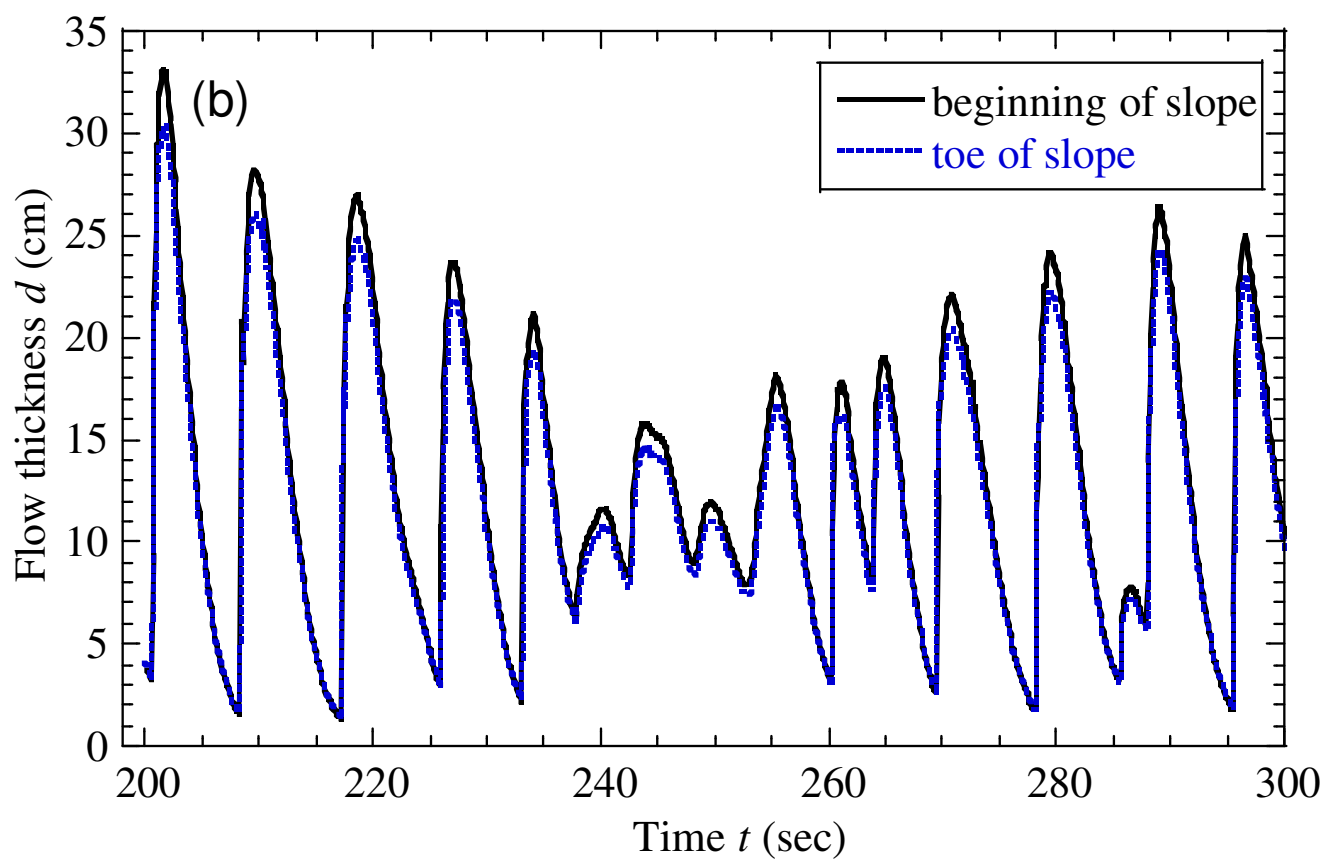

Fig. 15. Flow thickness time series at the beginning and at the toe of the land-side slope: (a) before time shifted, and (b) after time shifted (data from Trial 17). 


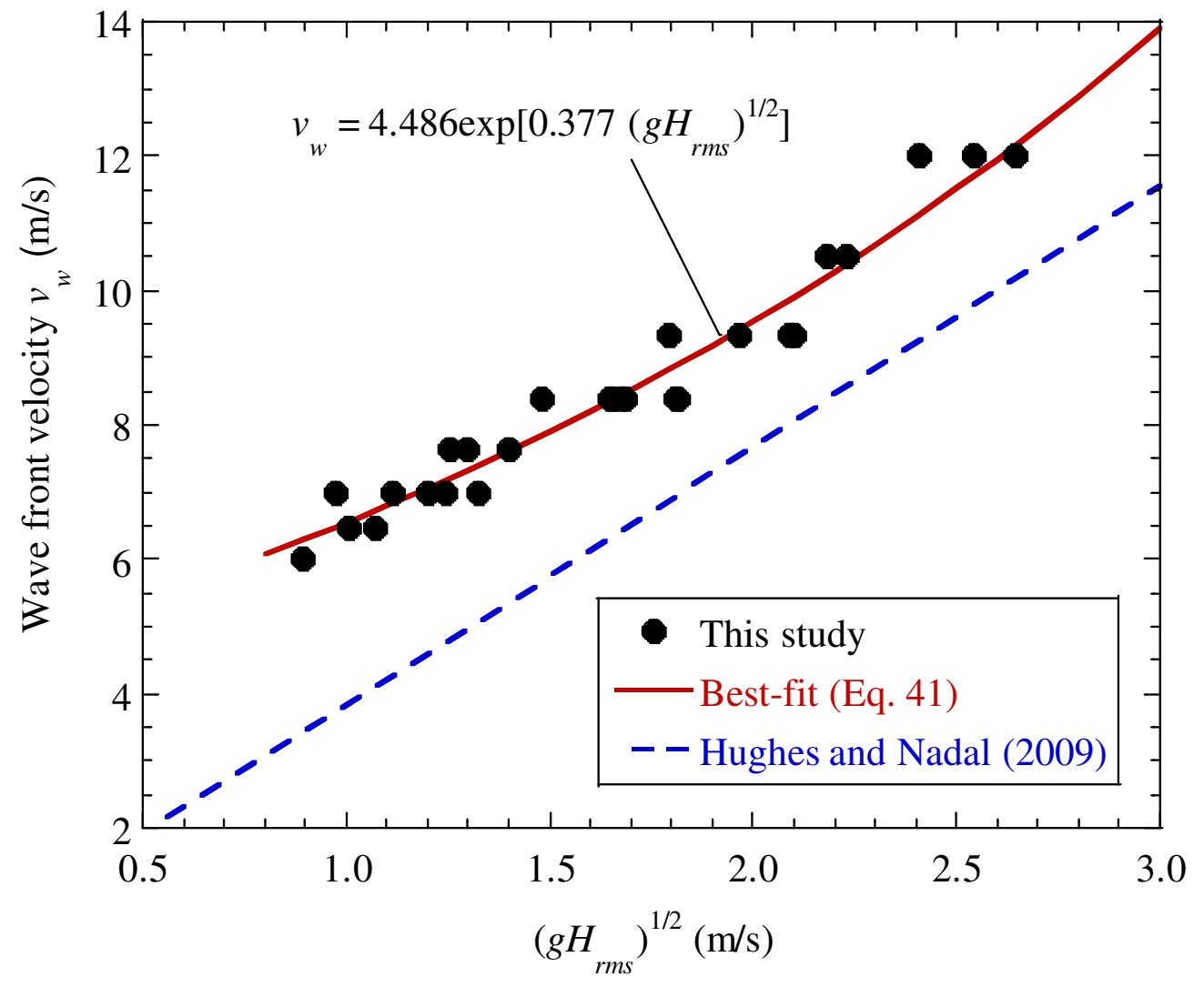

Fig. 16. Estimated wave front velocity on the land-side slope 